Arkivoc

Free to Authors and Readers
A Platinum Open Access Journal for Organic Chemistry
Review

Arkivoc 2021, part ii, 37-72

\title{
Synthesis of $y, \delta$-unsaturated amino acids by Claisen rearrangement - last 25 years
}

\author{
Monika Bilska-Markowska, ${ }^{a}$ Marcin Kaźmierczak, ${ }^{* a, b}$ and Henryk Koroniak ${ }^{a}$ \\ ${ }^{a}$ Faculty of Chemistry, Adam Mickiewicz University in Poznań, Uniwersytetu Poznańskiego 8, \\ 61-614 Poznań, Poland \\ ${ }^{b}$ Centre for Advanced Technologies, Adam Mickiewicz University in Poznań, Uniwersytetu Poznańskiego 10, \\ 61-614 Poznań, Poland \\ Email: marcin.kazmierczak@amu.edu.pl
}

In dedication to Professor Zbigniew Czarnocki on the occasion of his 66th anniversary

Received 08-17-2020

Accepted 09-19-2020

Published on line 09-27-2020

\section{Abstract}

This mini review summarizes achievements in the synthesis of $y, \delta$-unsaturated amino acids via Claisen rearrangements. The multitude of products that can be obtained using the discussed protocol shows that it is one of the most important reactions in organic synthesis. Moreover, many Claisen rearrangement products are building blocks in the synthesis of more complex molecules with potential biological activity.

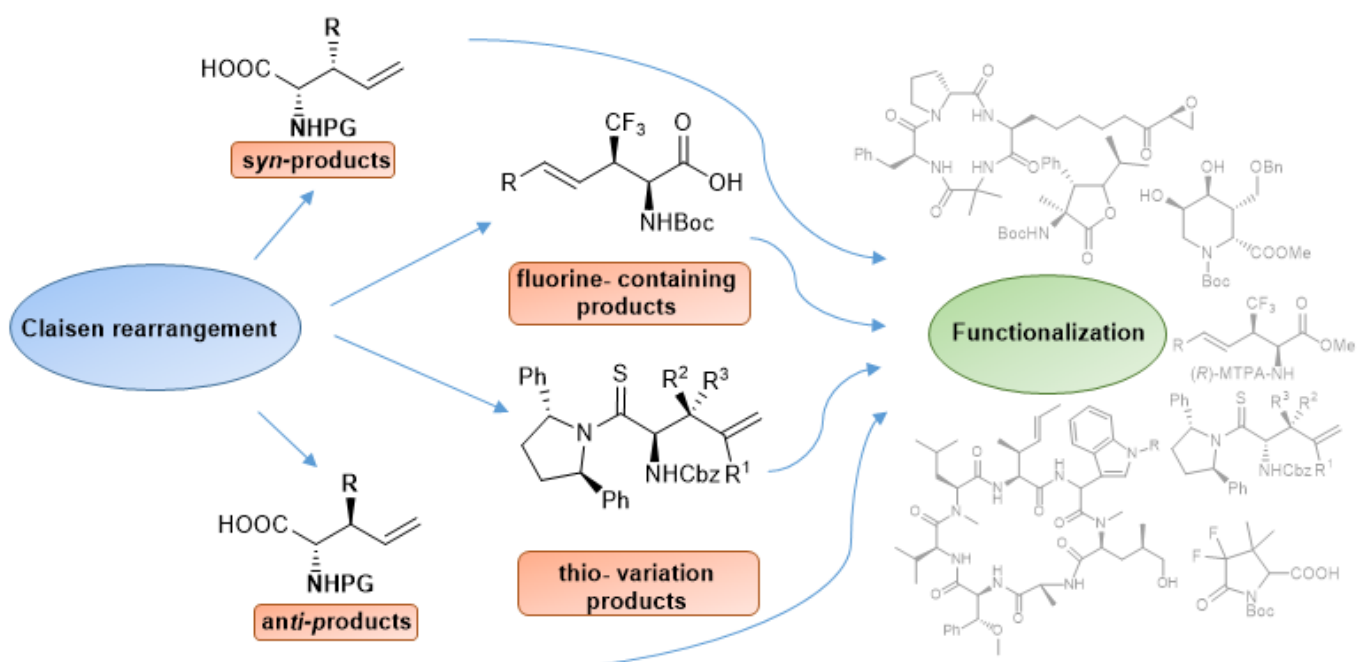

Keywords: $y, \delta$-Unsaturated amino acids, Claisen rearrangement, fluorine-containing $\gamma, \delta$-unsaturated amino acids, diastereoselectivity, optically active compounds 


\section{Table of Contents}

1. Introduction

2. Chelated Claisen Rearrangement

3. Related Versions of Claisen Rearrangement for $\gamma, \delta$-Unsaturated Amino Acids

4. Application of Claisen Rearrangement to the Synthesis of Fluorine-containing $\gamma, \delta$-Unsaturated Amino Acids

5. Conclusions

\section{Introduction}

Ludwig Claisen introduced the rearrangement in $1912,{ }^{1}$ and since then many aspects of this [3,3]-sigmatropic reaction have been investigated. The Claisen rearrangement is a pericyclic reaction involving a cyclic transition state, which delivers $\gamma, \delta$-unsaturated carbonyl compounds with a high predictability of the stereochemical outcome. $^{2}$ Generally, the Claisen rearrangement tolerates various substituents, as well as functional groups. Steglich et al. described for the first time a synthesis of a protected allylic glycine using this protocol in 1975. 3,4 The preparation of unnatural amino acids, especially with $\gamma, \delta$-unsaturation, has been of scientific interest for decades. ${ }^{5}$ It is mainly related to their a variety of biological activities. On the other hand, the Claisen rearrangement is a convenient way to extend application of a very reactive double bond towards the chemoselective synthesis, e.g. natural products. ${ }^{2,6}$ Moreover, $\gamma, \delta$-unsaturated amino acids can be used as molecular probes in the synthesis of stapled peptides. ${ }^{7}$

\section{Chelated Claisen Rearrangement}

A chelated Claisen rearrangement reaction is a very useful method for synthesis of organic molecules with defined stereochemistry. Diastereoselectivity of this reaction depends on a geometry of an enolate which is stabilized by a chelate formation. Moreover, researchers noted that during the reaction, a chair-like transition state $\mathbf{2}$ is created. Therefore stereochemical outcome of the rearrangement is controlled mainly by the transition state, the syn configured rearranged products are formed in a stereoselective fashion (Scheme 1)..$^{8,9}$

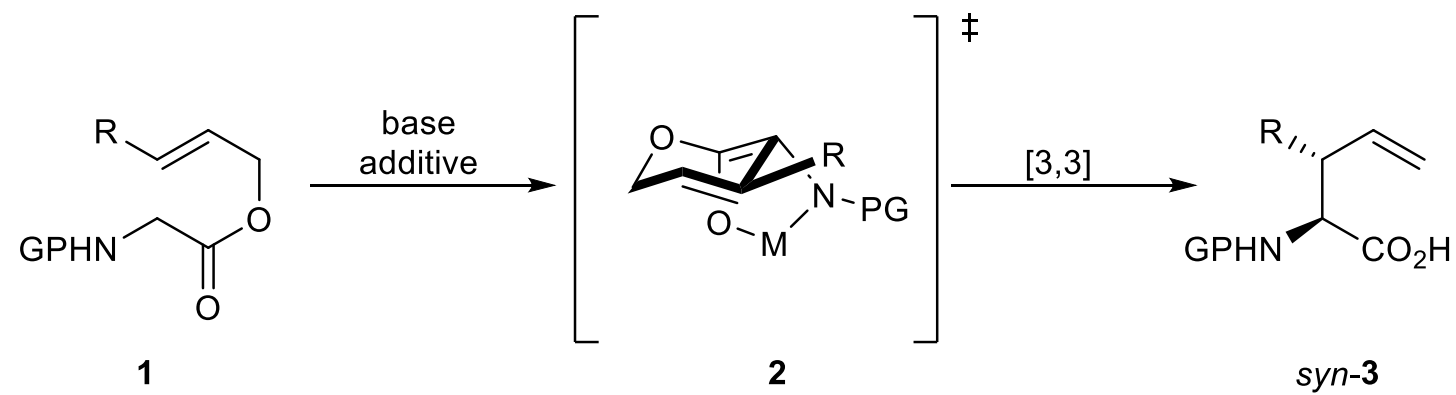

Scheme 1. The chelated Claisen rearrangement.

Kazmaier described this reaction based on the use of $\mathrm{N}$-protected glycine crotyl esters 4 in a presence of LDA and metal chlorides. After base driven deprotonation of substrate 4, addition of metal salts (such as: 
$\mathrm{ZnCl}_{2}, \mathrm{MgCl}_{2}, \mathrm{CoCl}_{2}$ ) was intended to convert the enolate ester into a chelate-bridged, stabilized carboxylate 5 (Table 1). This moiety undergoes rearrangement through a chair-like transition state when the reaction mixture is warmed to room temperature. The corresponding lithium enolates decompose completely without addition of metal chlorides and the rearrangement did not occur. The best results were achieved using $\mathrm{ZnCl}_{2}$, and rearranged syn acids 6 were obtained with very good diastereoselectivity and yields. The reaction can also be carried out using substrates with different blocking groups, e.g., Cbz, Boc, TFA, as well as with aliphatic substituents attached to the double bond of the starting substrates 4 (Table 1). ${ }^{10}$

Table 1. $\mathrm{ZnCl}_{2}$-catalyzed rearrangement of 4 and synthesis of $\mathbf{6}^{10}$

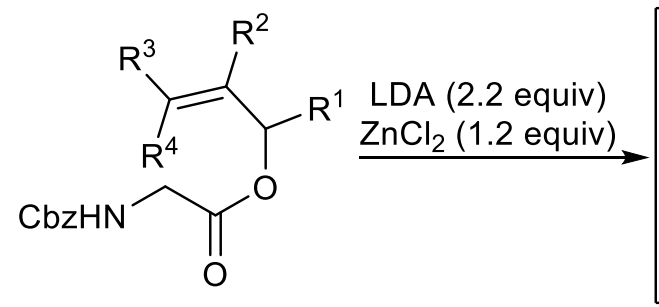

4

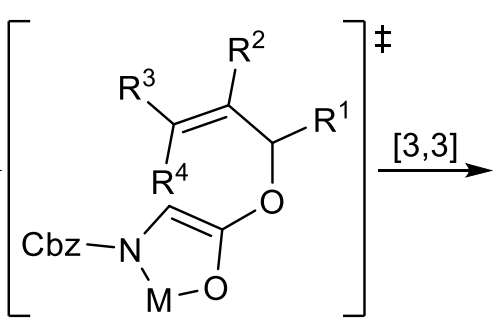

5

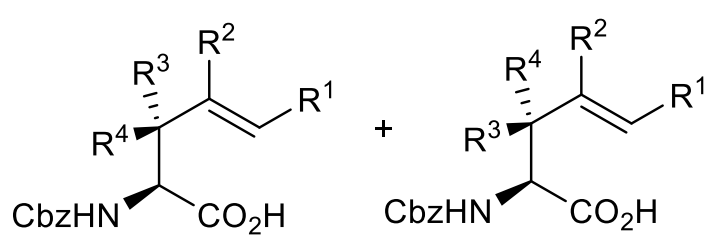

syn-(rac)-6 anti-(rac)-6

\begin{tabular}{cccccccc}
\hline Entry & $\mathrm{PG}$ & $\mathrm{R}^{1}$ & $\mathrm{R}^{2}$ & $\mathrm{R}^{3}$ & $\mathrm{R}^{4}$ & $d r$ & Yield (\%) \\
\hline 1 & $\mathrm{Cbz}$ & $\mathrm{H}$ & $\mathrm{H}$ & $\mathrm{H}$ & $\mathrm{H}$ & - & 88 \\
2 & $\mathrm{Cbz}$ & $\mathrm{H}$ & $\mathrm{Me}$ & $\mathrm{H}$ & $\mathrm{H}$ & - & 78 \\
3 & $\mathrm{Cbz}$ & $\mathrm{H}$ & $\mathrm{H}$ & $\mathrm{Pr}$ & $\mathrm{H}$ & $95: 5$ & 76 \\
4 & $\mathrm{Cbz}$ & $\mathrm{Me}$ & $\mathrm{H}$ & $\mathrm{Me}$ & $\mathrm{H}$ & $93: 7$ & 88 \\
5 & $\mathrm{Cbz}$ & $\mathrm{Et}$ & $\mathrm{H}$ & $\mathrm{Me}$ & $\mathrm{H}$ & $95: 5$ & 98 \\
6 & $\mathrm{Cbz}$ & $\mathrm{Et}$ & $\mathrm{H}$ & $\mathrm{H}$ & $\mathrm{Bu}$ & $95: 5$ & 73 \\
7 & $\mathrm{Boc}$ & $\mathrm{Me}$ & $\mathrm{H}$ & $\mathrm{Me}$ & $\mathrm{H}$ & $96: 4$ & 84 \\
8 & $\mathrm{Boc}$ & $\mathrm{H}$ & $\mathrm{H}$ & $\mathrm{Pr}$ & $\mathrm{H}$ & $96: 4$ & 78 \\
9 & $\mathrm{TFA}$ & $\mathrm{H}$ & $\mathrm{H}$ & $\mathrm{Pr}$ & $\mathrm{H}$ & $95: 5$ & 79 \\
10 & $\mathrm{TFA}$ & $\mathrm{Et}$ & $\mathrm{H}$ & $\mathrm{H}$ & $\mathrm{Bu}$ & $94: 6$ & 65 \\
11 & $\mathrm{Cbz}$ & $\mathrm{H}$ & $\mathrm{H}$ & $\mathrm{H}$ & $\mathrm{CH}_{2} \mathrm{OTBDPS}$ & $98.5: 1.5$ & 75 \\
\hline
\end{tabular}

The Claisen rearrangement reaction is often used in the synthesis of intermediates of complex molecules. A similar protocol was used in the synthesis of a building block, in the preparation of Cyclomarins 7, novel antimalarial and antitubercular agents (Figure 1). ${ }^{11}$ In the total synthesis of Chlamydocin 8 , a cyclic peptide showing histone deacetylase (HDAc) inhibition, the chelated Claisen reaction was one of the key steps (Figure 1)..$^{12}$

The discussed procedure can also be applied to $\mathrm{N}$-protected allylic esters of $\alpha, b$-unsaturated amino acids 9 (Table 2). The rearrangement products contain both allylic, and vinyl moieties in their structure. In case of reaction of 9(3), apart from desired rearrangement product 10(3), a side product was observed resulting from a cleavage of the $\mathrm{Cbz}$ group. Compounds $\mathbf{1 0}$ can be used as substrates for their further modification in the synthesis of potentially biologically active compounds. ${ }^{13}$ 


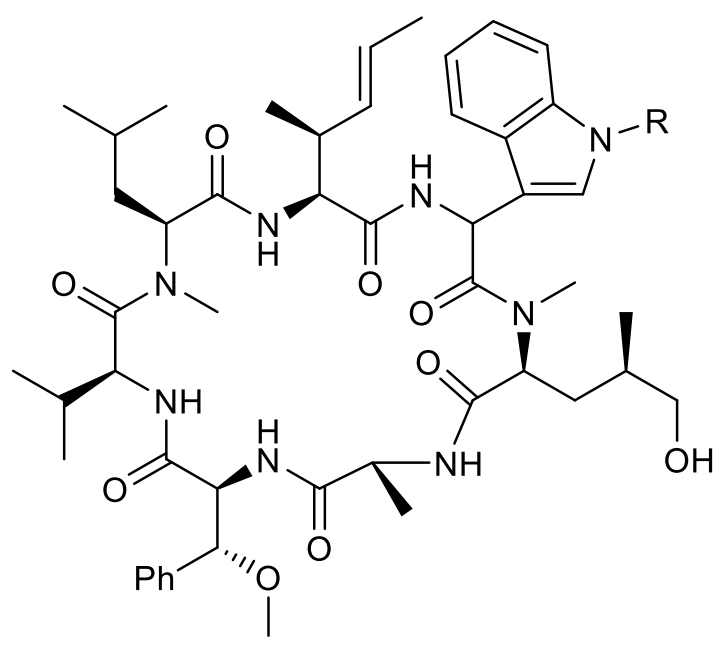

7<smiles>CC1(C)NC(=O)[C@H](CCCCCC(=O)[C@@H]2CO2)NC(=O)[C@@H]2CCCN2C1=O</smiles>

8

Figure 1. Chemical structures of Cyclomarins 7 and Chlamydocin 8.

Table 2. Rearrangement of $\mathrm{N}$-protected allylic esters of $\alpha, 6$-unsaturated amino acids 9 to give compounds $10^{13}$<smiles>[R]C/C=C(/NC(=O)OCc1ccccc1)C(=O)OC([R])/C=C/C</smiles>

9 i) LDA (2.2 equiv) $\mathrm{ZnCl}_{2}(1.2$ equiv) ii) $\mathrm{H}_{3} \mathrm{O}^{+}$

\begin{tabular}{cccc}
\hline Entry & $\mathrm{R}^{1}$ & $\mathrm{R}^{2}$ & Yield (\%) \\
\hline 1 & $\mathrm{Me}$ & $\mathrm{Me}$ & 61 \\
2 & $\mathrm{H}$ & $\mathrm{Ph}$ & 53 \\
3 & $\mathrm{Me}$ & $\mathrm{H}$ & - \\
\hline
\end{tabular}

Moreover, formation of the diallylated amino acid $\mathbf{1 2}$ is also possible by chelated Claisen rearrangement (Scheme 2). During the reaction, two chiral centers are introduced diastereoselectively $(d s=93 \%) .{ }^{14}$<smiles>C=CCC(NC(=O)OCc1ccccc1)C(=O)OC/C=C/C</smiles>

11

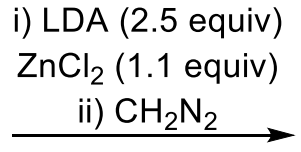

CbzHN

$12(64 \%)$

Scheme 2. Synthesis of the diallylated amino acid $12 .{ }^{14}$

The chelated Claisen rearrangement can also take place in sterically crowded substrates 13. Kazmaier postulate the formation of a chelated metal enolate as the key step in such synthesis (Table 3). TFA was used 
as a nitrogen blocking group; the substituents of $\mathrm{R}$ were both aliphatic and aromatic groups. The best results were obtained by applying $\mathrm{ZnCl}_{2}$ or $\mathrm{MgCl}_{2}$ as enole chelating agents. As a result $\gamma, \delta$-unsaturated amino acids 14 were synthesized with very good yields and diastereselectivity (Table 3). ${ }^{15}$

Table 3. Chelated Claisen rearrangement of 13 to give $\gamma, \delta$-unsaturated amino acids $14^{15}$

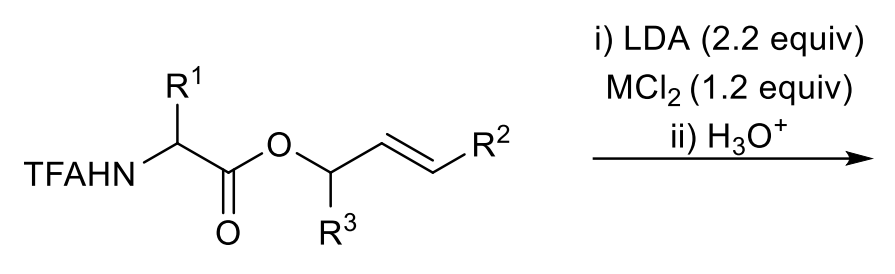

13<smiles>[R]C=CC([R2])[C@@]([R2])(NC[InH])C(=O)O</smiles>

syn-(rac)-14

\begin{tabular}{ccccccc}
\hline Entry & $\mathrm{R}^{1}$ & $\mathrm{R}^{2}$ & $\mathrm{R}^{3}$ & $\mathrm{MCl}_{2}$ & de (\%) & Yield (\%) \\
\hline 1 & $\mathrm{H}$ & $\mathrm{Me}$ & $\mathrm{H}$ & $\mathrm{ZnCl}_{2}$ & 88 & 86 \\
2 & $\mathrm{H}$ & $\mathrm{Me}$ & $\mathrm{H}$ & $\mathrm{MgCl}_{2}$ & 82 & 81 \\
3 & $\mathrm{Me}$ & $\mathrm{Me}$ & $\mathrm{H}$ & $\mathrm{ZnCl}_{2}$ & 96 & 84 \\
4 & $\mathrm{Me}$ & $\mathrm{Me}$ & $\mathrm{H}$ & $\mathrm{MgCl}_{2}$ & 90 & 83 \\
5 & $\mathrm{Me}$ & $\mathrm{Ph}$ & $\mathrm{H}$ & $\mathrm{ZnCl}_{2}$ & 94 & 65 \\
6 & $\mathrm{Me}$ & $\mathrm{Ph}$ & $\mathrm{H}$ & $\mathrm{MgCl}_{2}$ & 90 & 54 \\
7 & $\mathrm{Me}$ & $\mathrm{Me}$ & $\mathrm{Et}$ & $\mathrm{ZnCl}_{2}$ & 92 & 84 \\
8 & $\mathrm{Me}$ & $\mathrm{Me}$ & $\mathrm{Et}$ & $\mathrm{MgCl}_{2}$ & 94 & 89 \\
\hline
\end{tabular}

The stereoselective synthesis of optically active $(2 S, 3 S) \gamma, \delta$-unsaturated amino acid esters 16 is an example of a chelated Claisen rearrangement reaction (Table 4). Allylic amino acid esters 15 were obtained from chiral allylic alcohols and $\mathrm{N}-\mathrm{Boc}$ protected glycine or alanine in a DCC coupling reaction. The $\gamma, \delta$-unsaturated amino acid esters 16 have a high synthetic potential attributed to their structure. The authors highlighted the usefulness of these compounds in the synthesis of lactones $\mathbf{1 7}$ and $\mathbf{1 8}$ in ozonolysis/reduction or iodolactonization reactions (Figure 2). ${ }^{16}$

Table 4. Rearrangement reaction of 15 into amino acid esters $16^{16}$

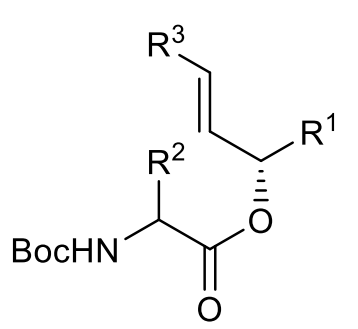

15

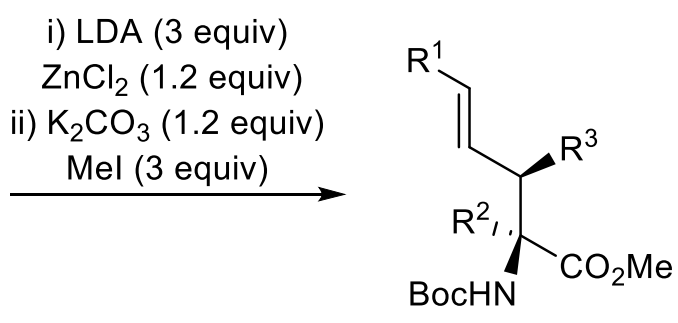

16 
Table 4. Continued

\begin{tabular}{ccccccc}
\hline Entry & $\mathrm{R}^{1}$ & $\mathrm{R}^{2}$ & $\mathrm{R}^{3}$ & $d s(\%)$ & ee (\%) & Yield (\%) \\
\hline 1 & $\mathrm{Me}$ & $\mathrm{H}$ & $\mathrm{Ph}$ & $>99$ & $>99$ & 84 \\
2 & $\mathrm{Me}$ & $\mathrm{Me}$ & $\mathrm{Ph}$ & $>99$ & $>99$ & 87 \\
3 & $\mathrm{Et}$ & $\mathrm{Me}$ & $\mathrm{Ph}$ & $>99$ & $>99$ & 88 \\
4 & $\mathrm{Me}$ & $\mathrm{H}$ & 4-MeOC $\mathrm{H}_{4}$ & $>99$ & 97 & 69 \\
5 & $\mathrm{Me}$ & $\mathrm{H}$ & 2-NAPH & $>99$ & 99 & 79 \\
6 & $\mathrm{Me}$ & $\mathrm{H}$ & 4- $\mathrm{-}$ ol & 98 & $>99$ & 84 \\
7 & $\mathrm{Me}$ & $\mathrm{Me}$ & 4- $\mathrm{BrC}_{6} \mathrm{H}_{4}$ & $>99$ & 98 & 83 \\
8 & $\mathrm{Et}$ & $\mathrm{Me}$ & 4- $\mathrm{BrC}_{6} \mathrm{H}_{4}$ & 97 & $>99$ & 89 \\
\hline
\end{tabular}<smiles>C[C@]1(NC(=O)OCc2ccccc2)C(=O)OC[C@H]1c1ccccc1</smiles>

17<smiles>CC(C)C1OC(=O)[C@](C)(N=C(O)c2ccccc2)[C@H]1c1ccccc1</smiles>

18

Figure 2. Chemical structures of lactones $\mathbf{1 7}$ and $\mathbf{1 8 .}$

Kazmaier also wanted to use such a protocol in a synthesis of functionalized peptides 20. However, when $\mathrm{ZnCl}_{2}$ was used for chelation, low yields were obtained (20\%). As it turned out, the chelated Claisen rearrangement can also be successfully carried out in the presence of $\mathrm{MnCl}_{2}$, obtaining products with yields up to $98 \%$ (Table 5$).{ }^{17}$

Table 5. $\mathrm{MnCl}_{2}$-catalyzed rearrangement of 19 to give peptides $20^{17}$

PG-AS-HN

19
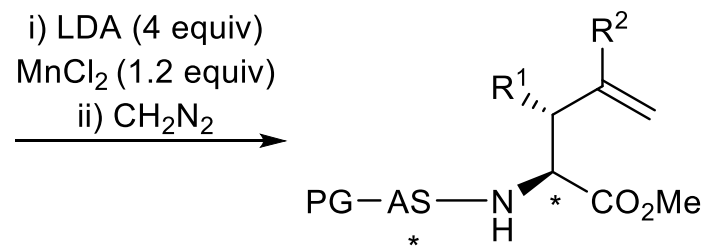

$(S, S)-20$

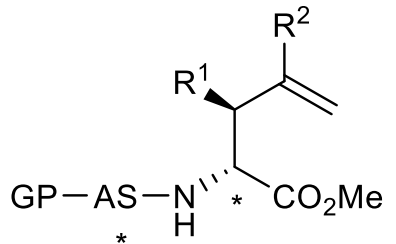

$(S, R)-20$ 
Table 5. Continued

\begin{tabular}{ccccccc}
\hline Entry & $\mathrm{PG}$ & $\mathrm{AS}$ & $\mathrm{R}^{1}$ & $\mathrm{R}^{2}$ & SS:SR & Yield (\%) \\
\hline 1 & Boc & Val & $\mathrm{H}$ & $\mathrm{Me}$ & $51: 49$ & 88 \\
2 & $\mathrm{Boc}$ & $\mathrm{Phe}$ & $\mathrm{H}$ & $\mathrm{Me}$ & $63: 37$ & 90 \\
3 & $\mathrm{Cbz}$ & $\mathrm{Phe}$ & $\mathrm{H}$ & $\mathrm{Me}$ & $66: 34$ & 88 \\
4 & $\mathrm{Cbz}$ & $\mathrm{Val}$ & $\mathrm{Me}$ & $\mathrm{H}$ & $61: 39$ & 92 \\
5 & Boc & Val & $\mathrm{Me}$ & $\mathrm{H}$ & $37: 63$ & 93 \\
6 & Boc & Phe & $\mathrm{Me}$ & $\mathrm{H}$ & $62: 38$ & 93 \\
7 & TFA & Phe & $\mathrm{Me}$ & $\mathrm{H}$ & $47: 53$ & 98 \\
8 & $\mathrm{Ts}$ & Phe & $\mathrm{Me}$ & $\mathrm{H}$ & $35: 65$ & 92 \\
9 & $\mathrm{Ts}$ & lle & $\mathrm{Me}$ & $\mathrm{H}$ & $35: 65$ & 83 \\
10 & Boc & Met & $\mathrm{Me}$ & $\mathrm{H}$ & $33: 67$ & 88 \\
11 & Boc & Lys(Boc) & $\mathrm{Me}$ & $\mathrm{H}$ & $42: 58$ & 78 \\
\hline
\end{tabular}

Optimized reaction conditions could be adapted for peptide synthesis. Both sterically crowded 21, chiral 23, 25, as well as 6 -amino acid $\mathbf{2 7}$ derivatives, can be used as starting materials (Scheme 3 ). In each case, the rearrangement products were obtained with very good yields and diastereoselectivities. From the point of view of their potential application in medicine, the structures of the above compounds are interesting. What is more, they can be substrates for their further modification.<smiles>C/C=C/COC(=O)C(C)NC(=O)[C@H](Br)NC(=O)O</smiles>

21<smiles>C=C[C@H](CBr)OC(=O)CNC(=O)[C@H](C)NC(=O)OCc1ccccc1</smiles>

23<smiles>C=C[C@H](OC(=O)C(C)NC(=O)[C@@H](NC(=O)OCc1ccccc1)C(C)C)c1ccccc1</smiles>

25<smiles>C/C=C\COC(=O)CNC(=O)CC(N=C(O)c1ccccc1)c1ccccc1</smiles>

27

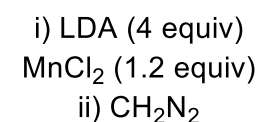<smiles>C=CC(C)C(C)(NC(=O)[C@H](Cc1ccccc1)NC(=O)c1ccccc1)C(=O)OC</smiles>

$22 d s=50 \%(95 \%)$

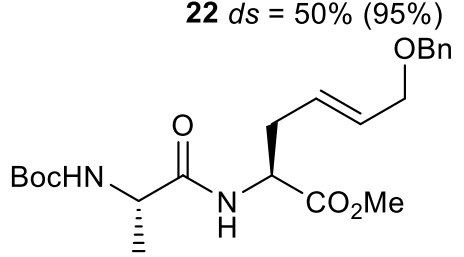

$24 d s=99 \%(94 \%)$

i) LiHMDS (4 equiv)

$\mathrm{MnCl}_{2}$ (1.2 equiv)<smiles>[R6]OC(=O)[C@@H](NC(=O)OC)C(=O)N[C@](C)(C/C=C/c1ccccc1)C(C)C</smiles>

i) LDA (4 equiv) $\mathrm{MnCl}_{2}$ (1.2 equiv)

ii) $\mathrm{CH}_{2} \mathrm{~N}_{2}$<smiles>C=CC(C)C(NC(=O)CC(NC(=O)OCc1ccccc1)c1ccccc1)C(C)=O</smiles>

$28(90 \%)$

Scheme 3. $\mathrm{MnCl}_{2}$-catalyzed rearrangement reactions. ${ }^{17}$ 
Examples of a chelated Claisen rearrangement of the crotyl ester of $N$-protected $B$-alanine $\mathbf{2 9}$ are also known in the literature (Table 6). Kim and coworkers carried out the reaction under standard Kazmaier-Claisen rearrangement conditions, obtaining $\mathbf{3 0}$ with a very good diastereoselectivity, which supported the formation of the corresponding chelated compound as an intermediate product. However, the yield of the reaction was not satisfactory. In all cases, the conversion of starting substrate $\mathbf{2 9}$ was incomplete, but the obtained ratio of syn:anti isomers $\mathbf{3 0}$ was up to 98:2. An increase of the yield of the reaction was possible by using the IrelandClaisen rearrangement conditions, but in this case the diastereoselectivity of the process slightly decreased (Table 6, entry 3). ${ }^{18} \mathrm{Kim}$ and coworkers tried the chelated Claisen rearrangement to obtain one of the building blocks needed for synthesis of (-)-Cephalotaxine. As it turned out, under standard conditions (LiHMDS or LDA and $\mathrm{Al}(\mathrm{O} i-\mathrm{Pr})_{3}$ or $\left.\mathrm{ZnCl}_{2}\right)$ the rearrangement reaction did not occur at all. On the other hand, application of the Ireland-Claisen rearrangement conditions afforded in the desired rearrangement product. ${ }^{19}$

Table 6. Chelated Claisen rearrangement of 6 -amino acid derivative $\mathbf{2 9}$ to isomers $\mathbf{3 0} 0^{18}$

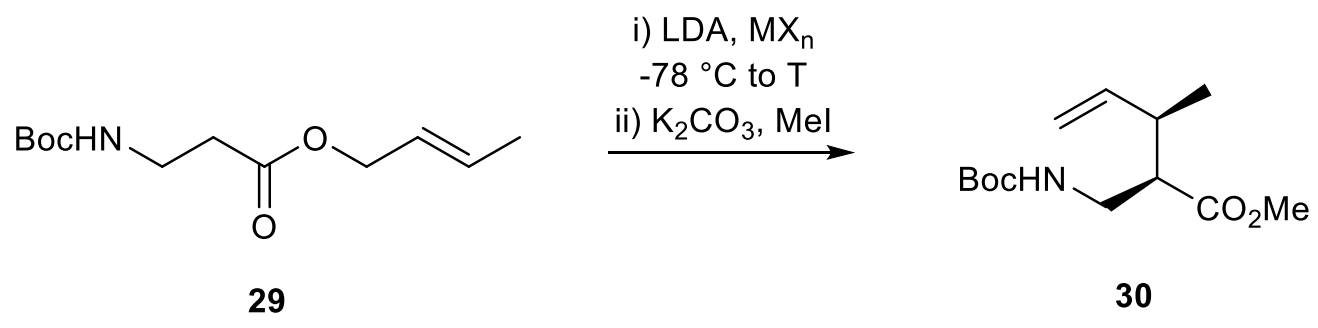

\begin{tabular}{ccccc}
\hline Entry & $\mathrm{MX}_{\mathrm{n}}$ & $\mathrm{T}\left({ }^{\circ} \mathrm{C}\right)$ & $d s$ & Yield (\%) \\
\hline 1 & $\mathrm{ZnCl}_{2}$ & $\mathrm{rt}$ & $96: 4$ & 35 \\
2 & $\mathrm{ClTi}(\mathrm{Oi}-\mathrm{Pr})_{3}$ & $\mathrm{rt}$ & $98: 2$ & 24 \\
3 & $\mathrm{ClSiMe}_{3}$ & 60 & $86: 14$ & 86 \\
\hline
\end{tabular}

The $\mathrm{Zn}$-chelated enolate variant of the Claisen rearrangement was used by Mohamed and Brook in the synthesis of $\alpha$-allylsilane functionalized amino acids (Scheme 4). ${ }^{20}$ This method gave acceptable results, both in terms of the reaction yield (50\%), and the diastereoselectivity (syn/anti, 23:1). However, a hydrolysis of the starting ester was observed in this approach. The use of Ireland-Claisen conditions gave satisfactory results. The order of the reagent addition was crucial: addition of the base to the ester increased the yield (82\%) and diastereoselectivity (29:1). The studies also proved the influence of the silyl groups ( $\mathrm{R}=\mathrm{Me}, i-\mathrm{Pr}, t-\mathrm{Bu}, \mathrm{Ph})$ on the stereoselectivity of the reaction. The best results were obtained for esters with methyl and isopropyl substituents.

The above-discussed chelated Claisen rearrangement may also run asymmetrically in the presence of chiral bidentate ligands (Scheme 5). ${ }^{21}$ The best asymmetric induction was observed for cinchona alkaloids. Probably, quinine coordinates as a bidentate ligand to the aluminum chiral to stabilize the lithium enolate $\mathbf{3 5}$ (Figure 3).22 The authors noted that the use of chiral amino alcohol, diol or diamine as a catalyst for this purpose did not give a significant asymmetric induction. The reactions proceeded under standard metal salt $\left(\mathrm{Al}(\mathrm{iOPr})_{3}\right.$ or $\left.\mathrm{Mg}(\mathrm{OEt})_{2}\right)$ /base (LDA) conditions, additionally a chiral ligand was added to the reaction mixture. 


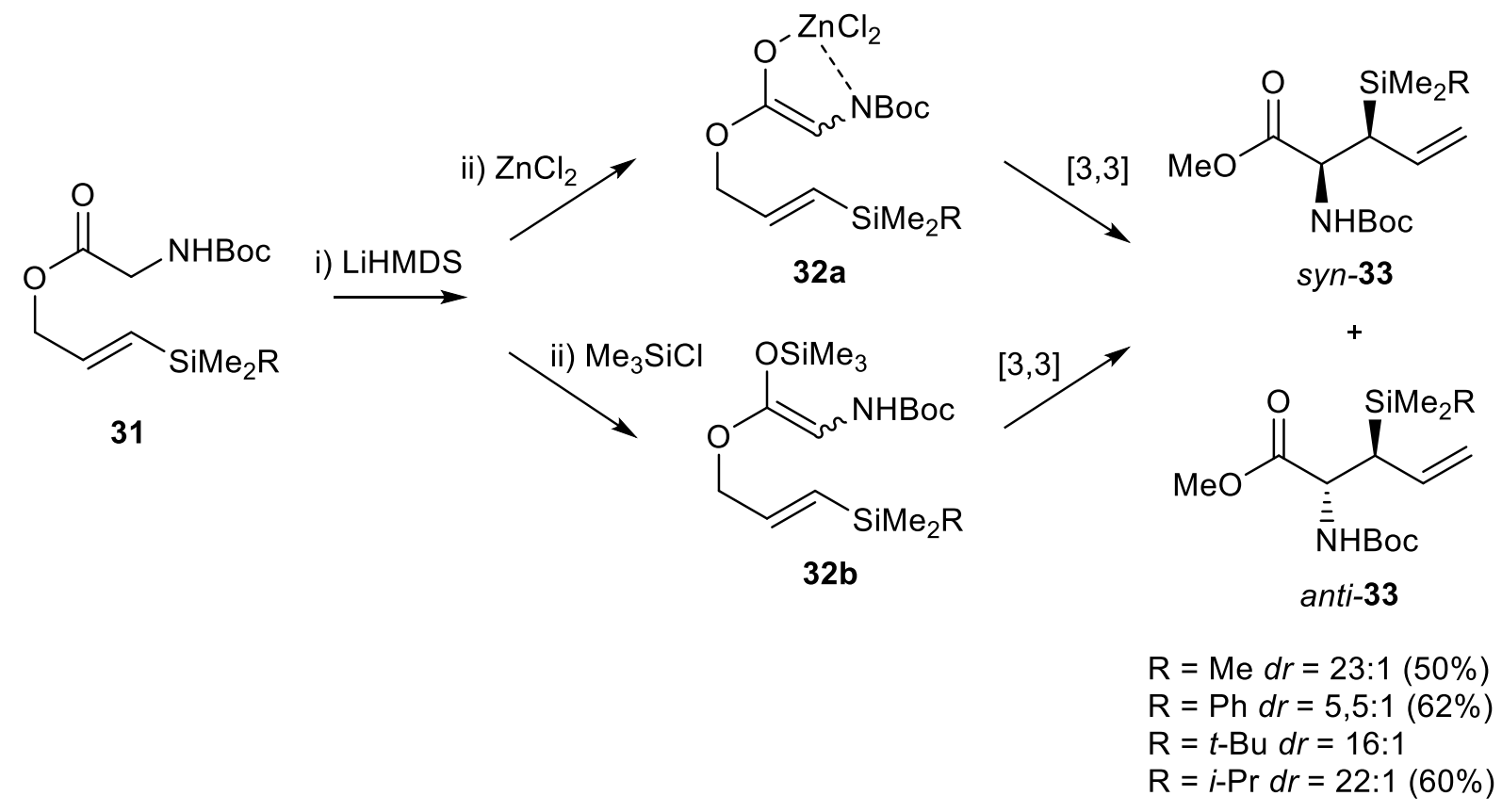

Scheme 4. Claisen rearrangement of silylallyl glycinate. ${ }^{20}$

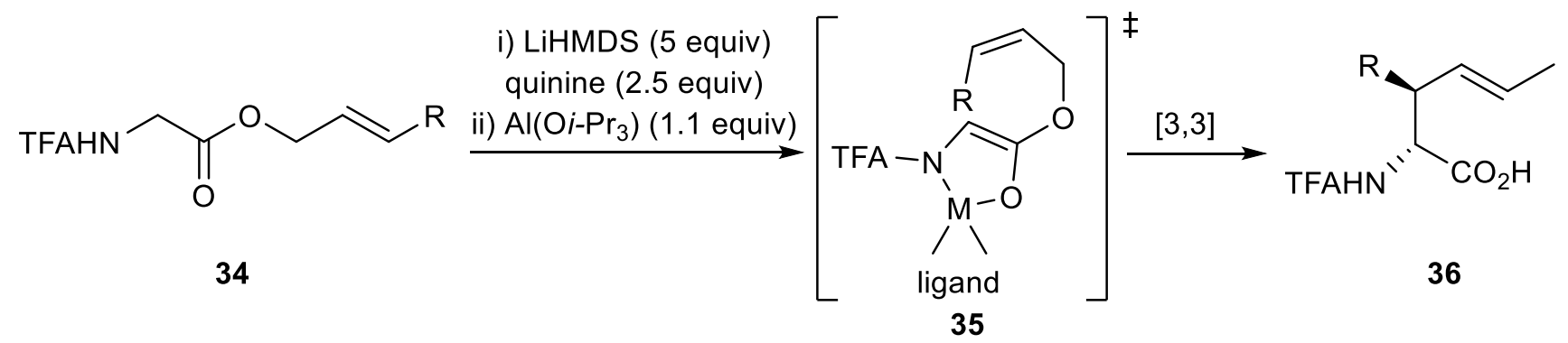

Scheme 5. Chelated Claisen rearrangement in the presence of quinine. ${ }^{21}$

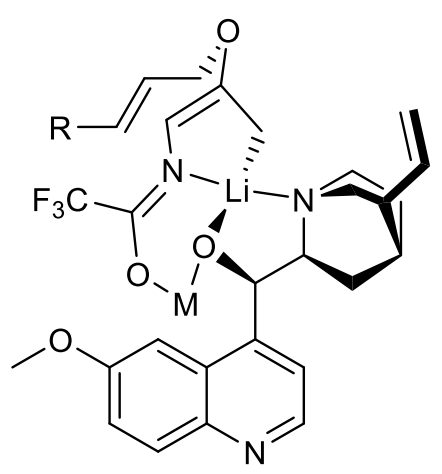

Figure 3. Structure of transition state $35 .^{22}$

In all cases, high diastereoselectivity was observed, much higher than without a presence of a chiral catalyst. Unnaturally configured $(2 R) \gamma, \delta$-unsaturated amino acids 36 (Table 7, entry 1-7) were obtained with high enantiomeric excesses (up to 90\%). The corresponding $2 S$ analogues 36 (Table 7, entry 8-9) were 
obtained when quinidine was employed. Kazmaier showed that the enantomeric purity was improved even up to $99.8 \%$ by crystallization of the crude product with S-(-)-phenylalanine or by enzyme-catalyzed resolution. ${ }^{23,24}$ Moreover, those enantiomeric pure compounds were further used in the synthesis of blocked isostatin $\mathbf{3 7}$ or diastereomerically pure hydroxyornithine derivative $\mathbf{3 8}$ (

Figure 4 4). ${ }^{23,25}$

Table 7. Synthesis of $\gamma, \delta$-unsaturated amino acids $36^{21}$

\begin{tabular}{ccccccc}
\hline Entry & $\mathrm{R}$ & chiral ligand & $d s(\%)$ & ee $(\%)$ & Yield (\%) & Conf. \\
\hline 1 & $\mathrm{H}$ & quinine & - & 80 & 92 & $(2 R)$ \\
2 & $\mathrm{Me}$ & quinine & 98 & 86 & 98 & $(2 R, 3 S)$ \\
3 & $\mathrm{Et}$ & quinine & 98 & 88 & 88 & $(2 R, 3 S)$ \\
4 & $n-\mathrm{Pr}$ & quinine & 98 & 80 & 87 & $(2 R, 3 S)$ \\
5 & $i-\mathrm{Pr}$ & quinine & 98 & 88 & 72 & $(2 R, 3 S)$ \\
6 & $t-\mathrm{Bu}$ & quinine & 98 & 90 & 66 & $(2 R, 3 R)$ \\
7 & $\mathrm{Ph}$ & quinine & 98 & 79 & 97 & $(2 R, 3 R)$ \\
8 & $\mathrm{Me}$ & quinidine & 98 & 86 & 96 & $(2 S, 3 R)$ \\
9 & $\mathrm{Ph}$ & quinidine & 98 & 82 & 95 & $(2 S, 3 R)$ \\
\hline
\end{tabular}<smiles>CC[C@H](C)[C@H](NC(F)F)[C@H](O)CC(=O)N[C@H](Cc1ccccc1)C(=O)OCc1ccccc1</smiles>

37<smiles>N#C[C@@H](O)C[C@H](NC(=O)OCc1ccccc1)C(=O)[O-]</smiles>

38

Figure 4. Chemical structures of isostatin $\mathbf{3 7}$ and hydroxyornithine $\mathbf{3 8 .}$

An Asymmetric chelate-Claisen rearrangement was adapted to $\delta$-benzyloxycrotyl ester 39 . The rearrangement occurred with very good efficiency and diastereoselectivity, but with moderate enantioselectivity. Nevertheless, the product of this transformation was crucial in the synthesis of the pipecolinic acid derivative $\mathbf{4 1}$ (Scheme 6). ${ }^{25}$

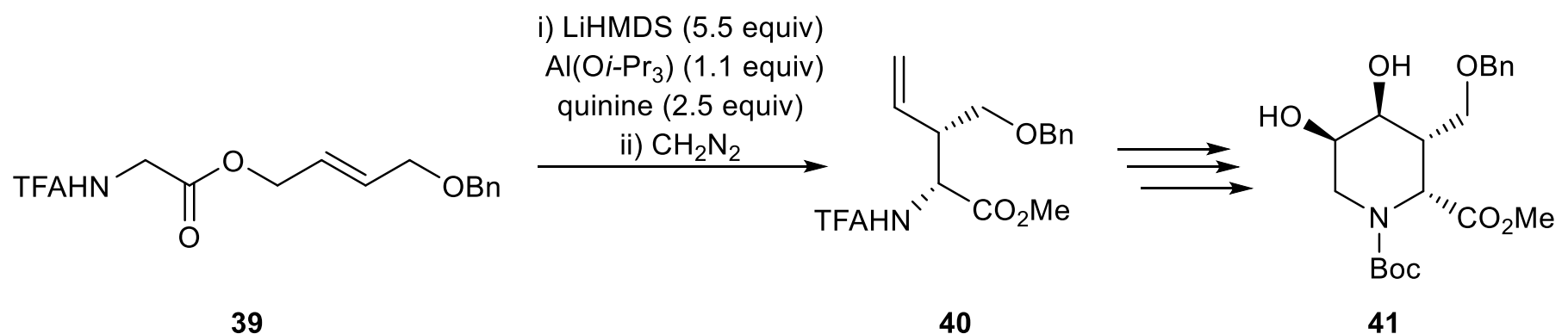

Scheme 6. Synthesis of pipecolinic acid $41 .^{20}$ 
Unsaturated amino acids can also be obtained via the chelated Claisen rearrangement of $\alpha$-stannylated esters 42 (Scheme 7). The substrates for this reaction can be obtained in a few steps from propargylic acetate or carbonate. The rearrangement itself takes place under the same conditions as its non-stannylated version. The first step is deprotonation with a base in the presence of $\mathrm{ZnCl}_{2}$ at $-78{ }^{\circ} \mathrm{C}$. When the reaction mixture is warmed to room temperature, a rearrangement occurs. Next, the resulting amino acids were immediately converted into their methyl esters $\mathbf{4 3}$ by treatment with diazomethane. The products undergo partial decomposition during purification on a chromatography column, therefore, they should be used promptly for subsequent reactions. ${ }^{26}$

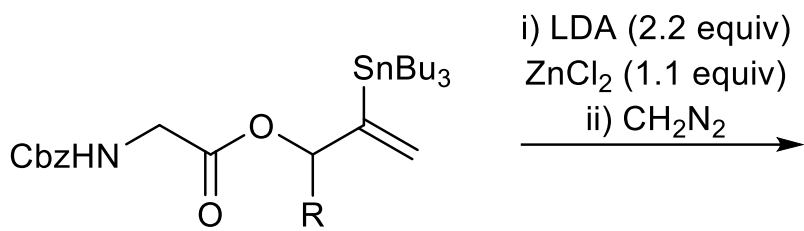

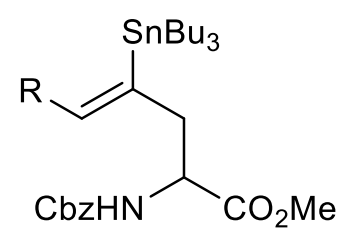

43a $\mathrm{R}=\mathrm{H}(70 \%)$

43b $R=\operatorname{Me}(46 \%)$

Scheme 7. Synthesis of methyl esters 43.

The derivatives containing a vinylstannane side chain can be used in the synthesis of highly functionalized, unsaturated amino acids, using the Still reaction. For example, derivatives $44 a-d$, and 45 , were obtained by a cross-coupling of stannanes with benzylbromide, bromobenzyl bromide, allylbromide, in the presence of [allylPdCl] 2 as a catalyst and $\mathrm{Ph}_{3} \mathrm{As}$ as a ligand. Vinyl iodide $\mathbf{4 6}$ was obtained by reacting $\mathbf{4 3 a}$ with iodine. This compound may be subjected to subsequent cross-coupling reactions. On the other hand, the synthesis of 47ab was possible when benzoyl or acetyl chloride and palladium catalyst were used (Figure 5). Due to the presence of the $\alpha, b$-unsaturated carbonyl group, these compounds can be applied as substrates for further modifications, e.g. in the Michael reaction. ${ }^{26,27}$

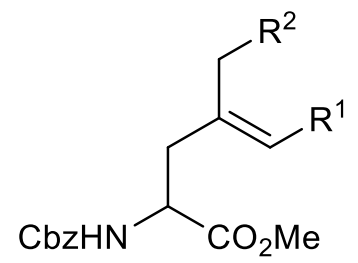
44a $\mathrm{R}^{1}=\mathrm{H}, \mathrm{R}^{2}=\mathrm{Ph}(81 \%)$
44b $\mathrm{R}^{2}=\mathrm{Me}, \mathrm{R}^{2}=\mathrm{Ph}\left(59 \%{ }^{*}\right)$
$45(57 \%)$
44c $\mathrm{R}^{1}=\mathrm{H}, \mathrm{R}^{2}=2-\mathrm{BrC}_{6} \mathrm{H}_{4}(58 \%)$
44d $\mathrm{R}^{2}=\mathrm{Me}, \mathrm{R}^{2}=2-\mathrm{BrC}_{6} \mathrm{H}_{4}\left(37 \%{ }^{*}\right)$

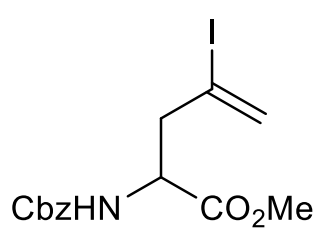

$46(95 \%)$<smiles>[R]C=C(CC(NC(=O)OC)C([R])=O)C(C)=O</smiles>

47a $\mathrm{R}^{1}=H, \mathrm{R}^{2}=\operatorname{Ph}(88 \%)$
47b $\mathrm{R}^{1}=\mathrm{Me}, \mathrm{R}^{2}=\mathrm{Ph}\left(52 \%{ }^{*}\right)$

*Overall yields for two steps (Claisen rearrangement and cross coupling).

Figure 5. Chemical structures of 44-47.

Mizota et al. proposed a one-pot synthesis of $\gamma, \delta$-unsaturated quaternary $\alpha$-alkylamino acids utilizing a Claisen rearrangement of the aluminium enolate obtained from umpolung reaction (Scheme 8 )..$^{28}$ First, imino 
ester 48 reacted with diethylaluminium chloride and ethylaluminium dichloride in DME then the reaction mixture was treated with diazomethane in $\mathrm{Et}_{2} \mathrm{O}$ at $0{ }^{\circ} \mathrm{C}$ for $10 \mathrm{~min}$.<smiles>[R]/C(=N/c1ccc(OC)cc1)C(=O)OCC=C</smiles>

48 i) $\mathrm{Et}_{2} \mathrm{AICl}$ (1 equiv)

$\mathrm{EtAICl}_{2}$ (1 equiv)

DME, $40{ }^{\circ} \mathrm{C}, 6-24 \mathrm{~h}$

ii) $\mathrm{H}_{2} \mathrm{O}$

iii) $\mathrm{CH}_{2} \mathrm{~N}_{2}, \mathrm{Et}_{2} \mathrm{O}, 0^{\circ} \mathrm{C}, 10 \mathrm{~min}$

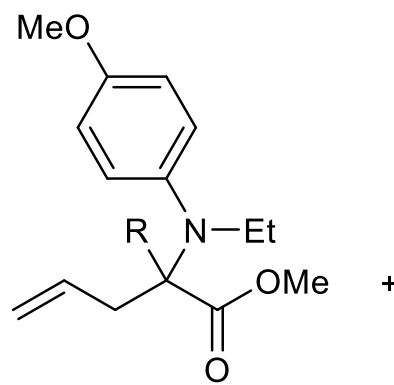

49<smiles>[R]C(C(=O)OCC=C)N(CC)c1ccc(OC)cc1</smiles>

50

Scheme 8. The umpolung reaction followed by a Claisen rearrangement. ${ }^{28}$

The yields of the desired compounds varied depending on the $\mathrm{R}$ substituent, as summarized in the Table 8 . The best results were obtained for molecules with an aromatic substituent, except for the 4-methoxyphenyl derivative (Table 8 , entry 6). Besides, the tert-butyl derivative gave no rearranged product (Table 8 , entry 9 ). Furthermore, sterically hindered alkylating reagents did not give the desired results. Reaction with diisobutyl aluminium chloride led to only $14 \%$ yield of the rearranged product. ${ }^{28}$

Table 8. Examination of the scope of substrates. ${ }^{28}$

\begin{tabular}{ccc}
\hline Entry & R substituent & Yield of compound 49 (\%) \\
\hline 1 & $\mathrm{Ph}$ & 60 \\
$2^{\mathrm{a}, \mathrm{b}}$ & $3-\mathrm{FC}_{6} \mathrm{H}_{4}$ & 76 \\
$3^{\mathrm{a}}$ & $4-\mathrm{FC}_{6} \mathrm{H}_{4}$ & 65 \\
$4^{\mathrm{c}}$ & $4-\mathrm{ClC}_{6} \mathrm{H}_{4}$ & 58 \\
5 & $3-\mathrm{MeOC}_{6} \mathrm{H}_{4}$ & 79 \\
$6^{\mathrm{a}, \mathrm{d}}$ & $4-\mathrm{MeOC}_{6} \mathrm{H}_{4}$ & 0 \\
$7^{\mathrm{e}, \mathrm{f}}$ & $2-\mathrm{Thienyl}^{\mathrm{f}}$ & \multicolumn{2}{c}{30} \\
$8^{\mathrm{a}}$ & $c-\mathrm{Hex}$ & 40 \\
9 & $t-\mathrm{Bu}$ & 0 \\
\hline
\end{tabular}

${ }^{\mathrm{a}} \mathrm{Et}_{2} \mathrm{AlCl}$ (2 equiv) was used. ${ }^{\mathrm{b}} \mathrm{N}$-Ethyl-4-methoxybenzenamine 50 was obtained in a $23 \%$ yield. ${ }^{\mathrm{c}} \mathrm{At}$ rt. ${ }^{\mathrm{d}} \mathrm{N}$-Ethyl4-methoxybenzenamine $\mathbf{5 0}$ was obtained in a $95 \%$ yield. e At $0{ }^{\circ} \mathrm{C} .{ }^{f} \mathrm{~N}$-Ethyl-4-methoxybenzenamine $\mathbf{5 0}$ was obtained in a $70 \%$ yield.

A Claisen rearrangement is used in organic synthesis not only to obtain directly $\gamma, \delta$-unsaturated amino acids but also to get their precursors ${ }^{29,30}$ that can be successfully transformed into non-natural amino acids. An excellent example of this type of application of the Claisen rearrangement reaction is the synthesis of $\alpha$ aminoaldehydes. Ricard et al. presented their approach using a $\mathrm{Cu}$-catalyzed vinylation reaction followed by a Claisen rearrangement. ${ }^{31}$ The 6 -allyloxyenamides $\mathbf{5 1}$ were synthesized by Cu-catalyzed coupling reaction between 6 -iodoenamides and allylic alcohols under mild conditions. Conventional heating of the compounds gave good yields of the rearrangement products, but the authors were not satisfied with the 
diastereoselectivity. Therefore, they tested the reaction conducting it with the use of microwave, both domestic and laboratory (Scheme 9).

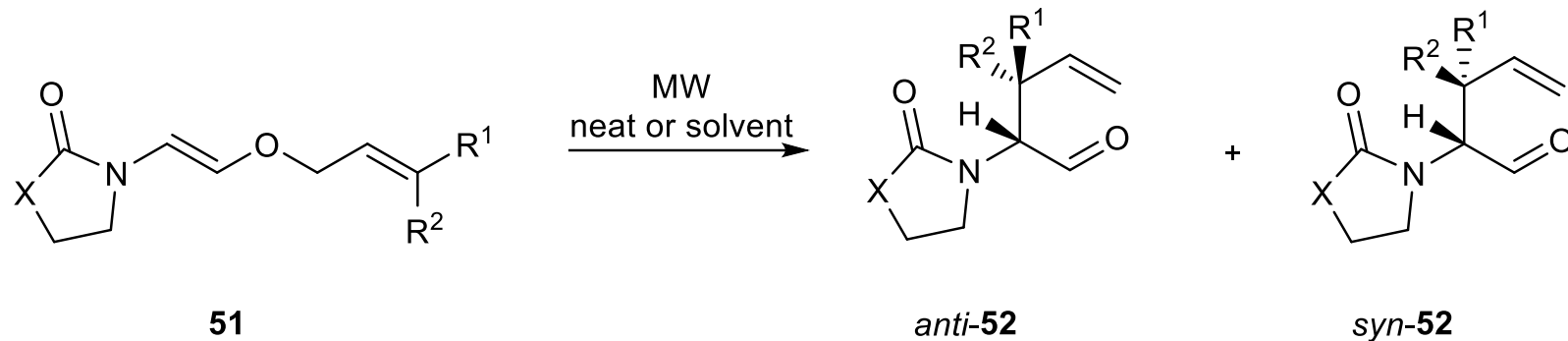

Scheme 9. Synthesis of $\gamma, \delta$-unsaturated $\alpha$-aminoaldehydes being amino acids precursors by a Claisen rearrangement of $B$-allyloxyenamides. ${ }^{31}$

Application of a domestic microwave produced satisfactory yields and acceptable selectivities. Encouraged by these achievements, the authors also used microwave heating. The reactions were quantitative and led to a very good $d r$ (Table 9). The presence of a solvent in the case of domestic microwave heating reduced the time of the process, while its type influenced the selectivity.

Table 9. The results of the reaction using domestic and laboratory microwave heating ${ }^{31}$

\begin{tabular}{|c|c|c|c|c|c|c|c|c|}
\hline \multirow[b]{2}{*}{ Entry } & \multirow[b]{2}{*}{$\begin{array}{c}\text { Substrate } \\
51\end{array}$} & \multirow{2}{*}{$\begin{array}{c}X \\
R^{1}, R^{2}\end{array}$} & \multirow{2}{*}{$\begin{array}{c}\text { Product } \\
52 \\
\end{array}$} & \multicolumn{5}{|c|}{$\begin{array}{c}\text { Yield }(\%) \\
{\text { (anti/syn ratio })^{a}}^{\text {Reaction time (min) }}\end{array}$} \\
\hline & & & & \multicolumn{4}{|c|}{ Domestic $\mathrm{MW}^{\mathrm{b}}$} & Lab MW \\
\hline & & & & Neat & DMF & $\mathrm{H}_{2} \mathrm{O}$ & $\begin{array}{c}\text { Ethylene } \\
\text { glycol }\end{array}$ & Neat \\
\hline 1 & $51 a$ & $\begin{array}{l}\mathrm{CH}_{2} \\
\mathrm{H}, \mathrm{H}\end{array}$ & & $\begin{array}{c}96 \\
(-) \\
1\end{array}$ & - & - & - & $\begin{array}{c}>99 \\
(-) \\
5\end{array}$ \\
\hline 2 & $51 b$ & $\begin{array}{c}\mathrm{O} \\
\mathrm{H}, \mathrm{H}\end{array}$ & & $\begin{array}{c}92 \\
(-) \\
1\end{array}$ & - & - & - & $\begin{array}{c}>99 \\
(-) \\
5\end{array}$ \\
\hline 3 & 51c & $\begin{array}{c}\mathrm{CH}_{2} \\
\mathrm{CH}_{2} \mathrm{CH}_{2} \mathrm{CH}_{3}, \mathrm{H}\end{array}$ & & $\begin{array}{c}94 \\
(4: 1) \\
5\end{array}$ & $\begin{array}{c}90 \\
(1.5: 1) \\
2\end{array}$ & $\begin{array}{c}82 \\
(6.1: 1) \\
2\end{array}$ & $\begin{array}{c}89 \\
(9: 1) \\
2\end{array}$ & $\begin{array}{c}>99 \\
(6.1: 1) \\
10\end{array}$ \\
\hline 4 & $51 d$ & $\begin{array}{c}\mathrm{O} \\
\left(\mathrm{CH}_{2}\right)_{2} \mathrm{CH}=\mathrm{C}\left(\mathrm{CH}_{3}\right)_{2}, \\
\mathrm{CH}_{3}\end{array}$ & & $\begin{array}{c}90 \\
(1: 6.1) \\
7\end{array}$ & $\begin{array}{c}88 \\
(1: 1.9) \\
4\end{array}$ & $\begin{array}{c}94 \\
(1: 6.1) \\
4\end{array}$ & $\begin{array}{c}91 \\
(1: 9) \\
3\end{array}$ & $\begin{array}{c}>99 \\
(1: 6.1) \\
15\end{array}$ \\
\hline
\end{tabular}

a Based on the $200 \mathrm{MHz}{ }^{1} \mathrm{H}$ NMR spectra of the crude reaction mixture.

b 30 s pulses of heat at maximum intensity $(700 \mathrm{~W})$.

${ }^{c}$ Continuous heating at maximum intensity (400 W). 


\section{Related Versions of Claisen Rearrangement for $\gamma, \delta$-Unsaturated Amino Acids}

For two reasons the $b$-substituted $\gamma, \delta$-unsaturated amino acids $\mathbf{5 3}$ and $\mathbf{5 4}$ (Figure 6 ) attract the interest of scientists: Firstly, the functionalization at the $b$-carbon atom can give an access to desired pharmacophores; and secondly, the terminal double bond with its orthogonal reactivity allows further chemical modifications during peptides and peptidomimetics synthesis. ${ }^{32,33}$ The Kazmaier-Claisen rearrangement has become a very useful tool to the synthesis of these nonproteinogenic amino acids but this approach did not work for anti-bsubstituted compounds.

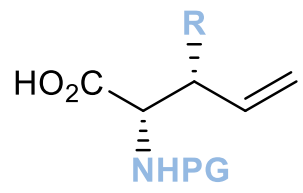

53

Kazmaier-Claisen rearrangement syn-product<smiles>[2H]C(C=C)C(N)C(=O)O</smiles>

54

\section{Eschenmoser-Claisen rearrangement anti-product}

Figure 6. Syn and anti- 6 -functionalized $\gamma, \delta$-unsaturated amino acids.

A new synthetic strategy for the construction of the anti- 6 -functionalized $\gamma, \delta$-unsaturated amino acids has been proposed by the Hruby research group. The Meerwein Eschenmoser-Claisen rearrangement constituted a crucial tool for the synthesis of desired compounds (Scheme 10). ${ }^{34}$ The secondary amines pyrrolidine 55a and $\mathrm{N}, \mathrm{N}$-diisopropylamine $\mathbf{5 5 b}$ were used to obtain glycine amide derivatives $\mathbf{5 6 a / 5 6 b}$. The commercially available allyl alcohols presented in Table 10 were applied for the rearrangement. During the optimization, it was important to carry out the reaction with a minimum of 2.2 equivalents of the alcohol to get good yields. 2,6-Di-tert-butylpyridine was essential for the triflic acid scavenging. The reactions afforded desired products with good to excellent diastereoselectivities (Table 10). ${ }^{34}$

Table 10. Investigation of the Eschenmoser-Claisen reaction conditions ${ }^{34}$

\begin{tabular}{|c|c|c|c|c|c|c|}
\hline Entry & Allyl alcohols & Alcohol equiv. & $\begin{array}{c}\mathrm{T} \\
\left({ }^{\circ} \mathrm{C}\right)\end{array}$ & $\begin{array}{c}\text { Time } \\
\text { (h) }\end{array}$ & anti/syn & $\begin{array}{c}\text { Yield }^{a} \\
(\%)\end{array}$ \\
\hline 1 & $\mathrm{HO}^{-}$ & 4 & $-35 \rightarrow \mathrm{RT}$ & 3.5 & N/A & $60 a-1(75)$ \\
\hline 2 & & 2.2 & $-35 \rightarrow 35$ & 4 & N/A & $60 a-2(44)$ \\
\hline \multirow{2}{*}{3} & & 2.2 & \multirow{2}{*}{$-35 \rightarrow \mathrm{RT}$} & 2 & 9.6:1 & $60 a-3(61)$ \\
\hline & & 2.2 & & 4 & 8.0:1 & 60b-3 (56) \\
\hline 4 & & 4 & $-35 \rightarrow \mathrm{RT}$ & 6 & N/A & $60 a-4(72)$ \\
\hline \multirow{2}{*}{5} & & 4 & \multirow{2}{*}{$-35 \rightarrow \mathrm{RT}$} & 4 & $16.8: 1$ & $60 a-5(74)$ \\
\hline & & 2.2 & & 17 & $20: 1$ & $60 b-5(77)$ \\
\hline
\end{tabular}

a Isolated yields. Compounds a are from pyrrolidinylamide, and compounds $\mathbf{b}$ are from diisopropylamide.

${ }^{b}$ Crotyl alcohol is a trans/cis mixture (95:5) from Sigma-Aldrich. 


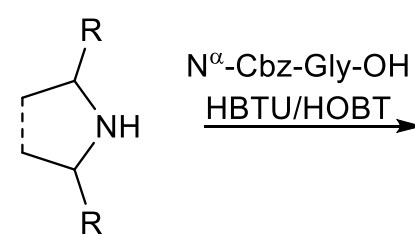

55a pyrrolidine 55b diisopropylamine<smiles>[R]C1CCC([R])N1C(=O)CNC(C)=O</smiles>

$56 a / 56 b$<smiles>[R]C1CCC([R])[N+]1=C(CN=C(OC)OC)OC</smiles>

$57 a / 57 b$<smiles>[R20]C(=C)C([R])([R])[C@H](N)C(=O)N1C([R])CCC1[R]</smiles>

60a pyrrolidinylamide $( \pm)$ 60b diisopropylamide $( \pm)$
MeOTf (2.2 equiv) 2,6-DTBP<smiles>[R]C([R])=C([R])C[GeH3]</smiles>

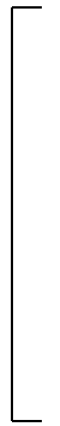<smiles>[R]C([R])=C([R])COC(=CN=C(OC)OCc1ccccc1)N1C([R])CCC1[R]</smiles>

$59 a / 59 b$

Scheme 10. The Meerwein Eschenmoser-Claisen rearrangement leading to anti- 6 -functionalized $\gamma, \delta$ unsaturated amino acids. ${ }^{34}$

This satisfying diastereoselectivity might be explained by (Z)-N,O-ketene acetal formation (Figure 7). In contrast to the intermediate of the Kazmaier-Claisen rearrangement with the enolate oxygen standing cis to the glycyl nitrogen, here the Eschenmoser-Claisen intermediate can accept two configurations presented in Figure 7 . The thermodynamically more stable $(Z)$-intermediate 61 a dominated likely the $(E)$ - $N, O$-ketene acetal 61b.<smiles>[R]OC(=CN=C(OC)OCc1ccccc1)N1CCCC1</smiles>

$61 \mathrm{a}$<smiles>[R]/C(=C/N=C(OC)OCc1ccccc1)N1CCCC1</smiles>

$61 \mathrm{~b}$

Figure 7. (Z)- and (E)-N,O-ketene acetal reaction intermediates. ${ }^{34}$

This method can also be used to synthesize other structural components of bioactive products, e.g. amino alcohols. Treating ( \pm )-60 with $\mathrm{LiAlH}(\mathrm{OMe})_{3}$ afforded amino aldehydes $\mathbf{6 2}$ that underwent epimerization during workup. Acidic, as well as basic conditions caused the racemization of amino aldehydes. Additionally, the $\gamma$ double bond and the 6 -substitution prompted the significant lability of the proton adjacent to the carbonyl. Reduction of these aldehydes led to several amino alcohols. By contrast, the employment of Lindgren oxidation conditions yielded the carboxylic acids (Scheme 11). 


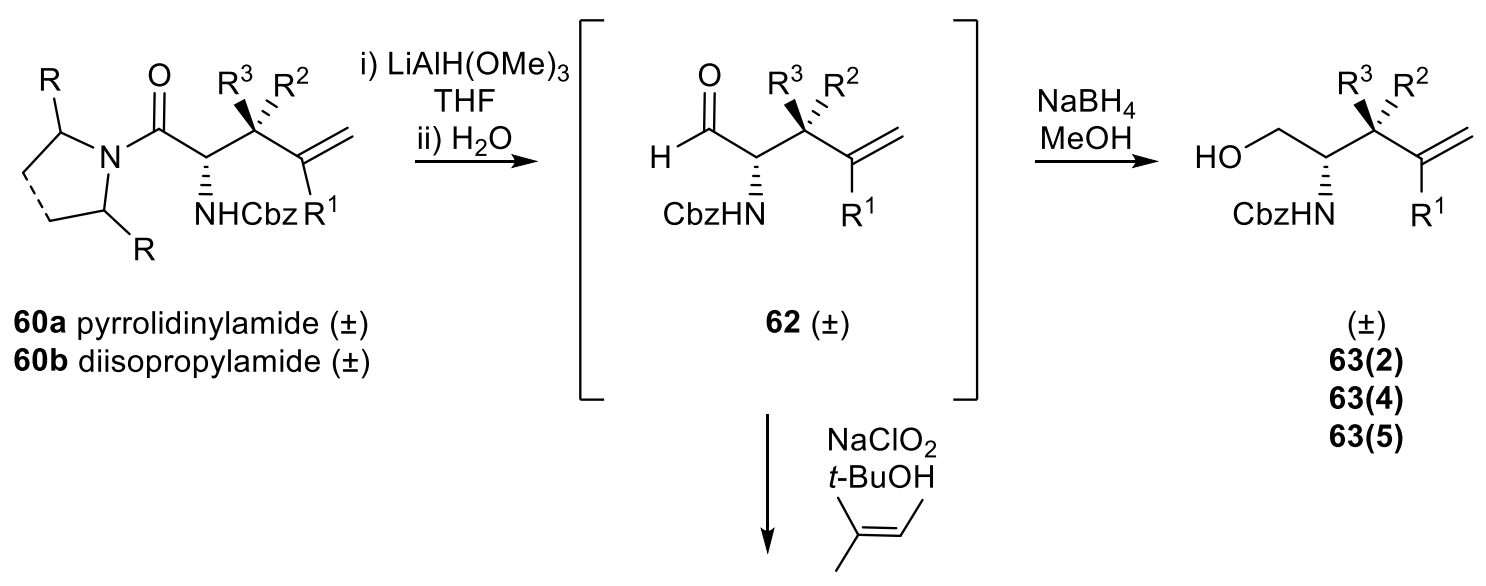<smiles>[R]C(=C)C([R])([R])[C@@H](NC(=O)O)C(=O)O</smiles>

$( \pm)$

64(3)

(1) $R^{1}, R^{2}, R^{3}=H$

(2) $R^{1}=H, R^{2}, R^{3}=M e$

(3) $R^{1}, R^{2}=H, R^{3}=M e$

(4) $R^{1}=M e, R^{2}, R^{3}=H$

(5) $R^{1}, R^{2}=H, R^{3}=P h$

Scheme 11. A reduction-hydrolysis with lithium trimethoxyaluminium hydride and sodium borohydride.

Optically active anti- $\beta$-functionalized $\gamma, \delta$-unsaturated amino acids are other building blocks that have attracted great interest because of their biological potential and the use for the synthesis of peptidomimetics. This type of amino acids were obtained in another study by the same group. ${ }^{35}$ The synthesis of these optically active compounds was accomplished by the asymmetric Eschenmoser-Claisen rearrangement, as the key step using a $C_{2}$-symmetric chiral auxiliary $(2 R, 5 R)$-dimethylpyrrolidine 65 (Scheme 12).
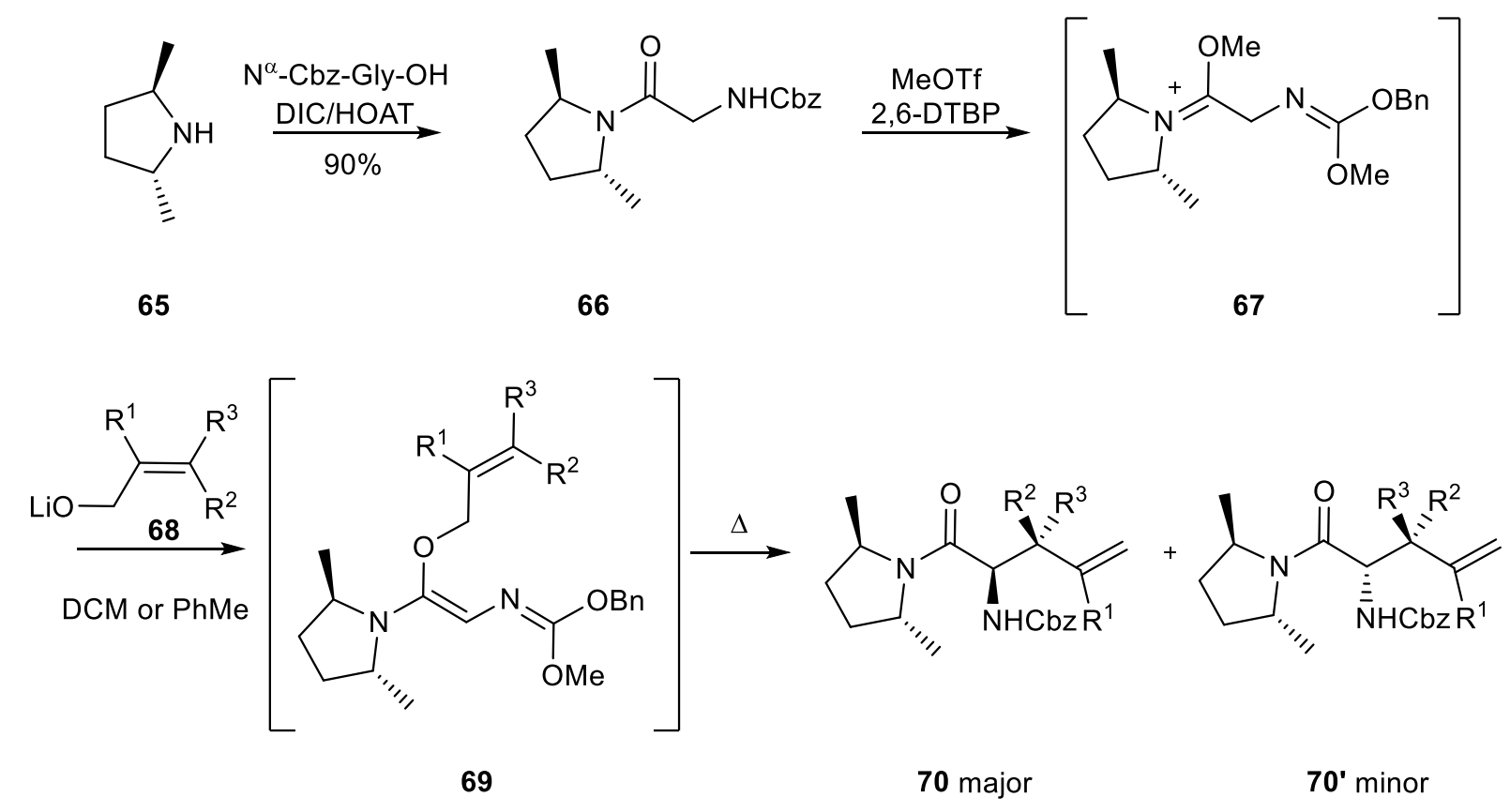

Scheme 12. An asymmetric Eschenmoser-Claisen rearrangement. ${ }^{35}$ 
A series of the same primary allylic alcohols were used in this asymmetric approach (Table 11). ${ }^{35}$ As previously mentioned, ${ }^{34}$ the excellent diastereoselectivity was attributed to the (Z)- $N, O$-ketene acetal formation and pseudo chair-like conformation of the rearrangement intermediate. As shown in the studies, the stereochemistry of the double bond had an effect on the diastereoselectivity. Trans alcohols had two substituents $\mathrm{R}^{1}$ and $\mathrm{R}^{3}$ away from the $C_{2}$-symmetric chiral auxiliary in the transition state and their size had no influence on a stereoselectivity (Table 11 , entries $4,5 \& 7$ ). The cis configured substituents of the allylic alcohols destabilized the chair-like transition state and decreased de (Table 11, entries $2 \& 6){ }^{35}$

Table 11. Results of the asymmetric Eschenmoser-Claisen rearrangement ${ }^{35}$

\begin{tabular}{|c|c|c|c|c|}
\hline Entry & Allyl alcohols & anti/syn & de (\%) 70:70' & 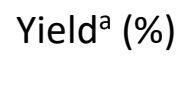 \\
\hline 1 & & N/A & $88^{b}$ & 75 \\
\hline 2 & & N/A & $49^{c}$ & 81 \\
\hline 3 & & N/A & $91^{b}$ & 82 \\
\hline 4 & $\mathrm{HO}^{-}$ & $>98: 2^{b}$ & $87^{b}$ & 85 \\
\hline 5 & & $>96: 4^{b}$ & $86^{b}$ & 83 \\
\hline 6 & & $>87: 13^{b}$ & $54^{b}$ & 65 \\
\hline 7 & $\mathrm{HO}^{-}$ & $>98: 2^{b}$ & $93^{c}$ & 70 \\
\hline
\end{tabular}

${ }^{a}$ Isolated yield of total isomers. ${ }^{b}$ Determined by chiral HPLC. ${ }^{c}$ Determined by ${ }^{1} \mathrm{H}$ NMR.

To remove the chiral auxiliary a two-step approach was applied (Scheme 13). The iodolactones formed in the first step were then subjected to zinc reduction giving the appropriate amino acids. The chiral auxiliary 65 has been recovered. This pathway gave good results except for derivative 70(7) (from allyl alcohol 7; $R^{1}, R^{2}=H$, $\mathrm{R}^{3}=\mathrm{Ph}$, Table 11), where formation of the syn isomer was also observed (Scheme 14). This was probably due to the electron-withdrawing nature of the phenyl group, which disfavored the formation of iodolactone, or it was unstable under the reaction conditions. Thus, compound $\mathbf{7 2 ( 7 )}$ was obtained by a reduction/oxidation of 70(7). The method presented by Hruby et al. allowed access to many new anti- $b$-functionalized $\gamma, \delta$ unsaturated amino acids with satisfactory diastereoselectivity. ${ }^{35}$ 


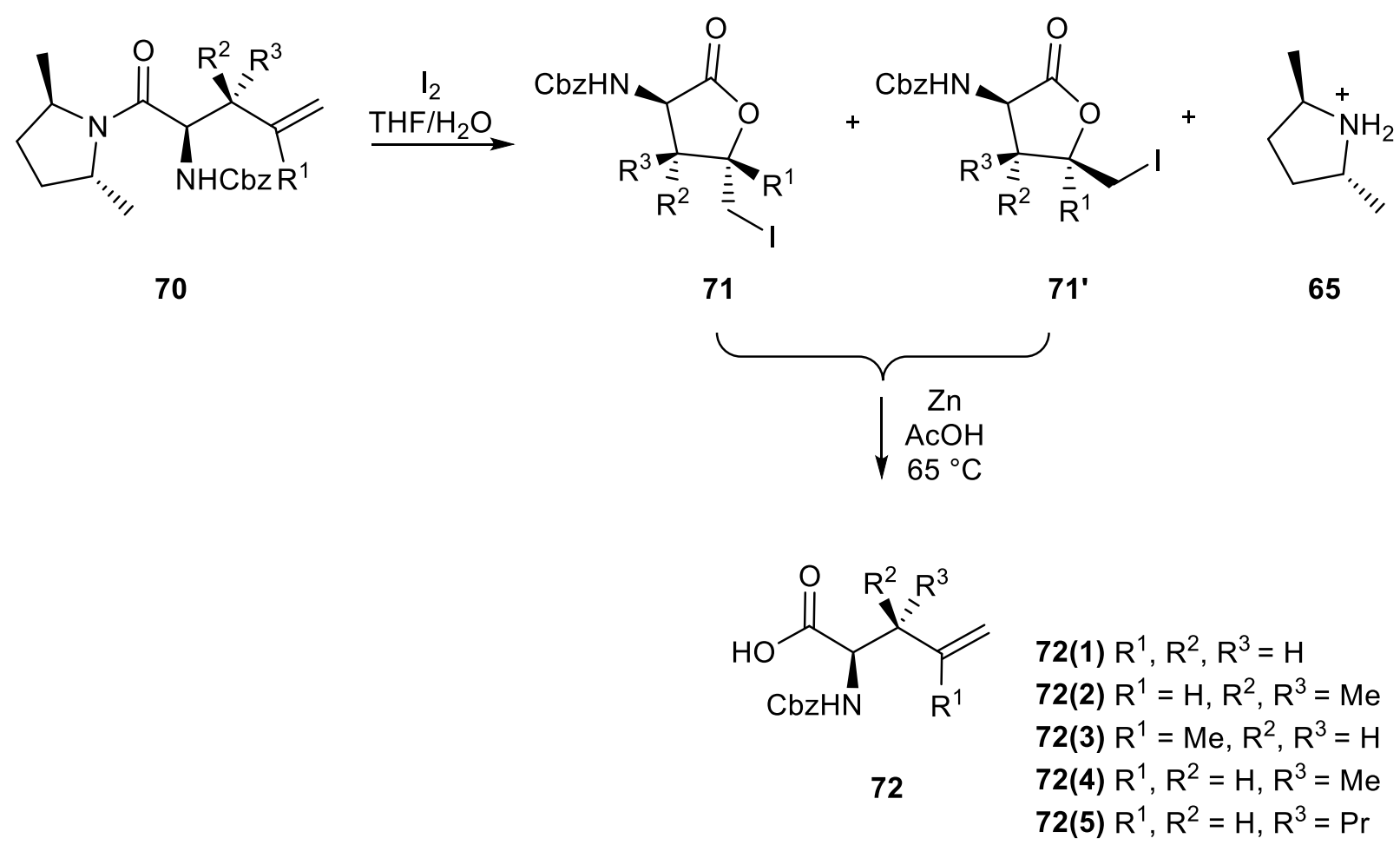

Scheme 13. The iodolactonization and zinc reduction of major anti products of the asymmetric EschenmoserClaisen rearrangement. ${ }^{35}$

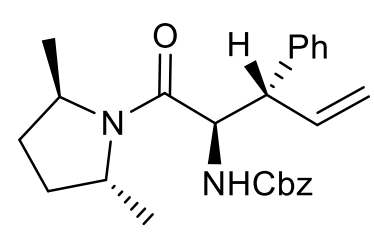

70(7) i) $\mathrm{LiAlH}(\mathrm{OMe})_{3}$, THF

ii) $\mathrm{H}_{2} \mathrm{O}$

$\stackrel{\text { iii) } \mathrm{NaBH}_{4}, \mathrm{MeOH}}{\longrightarrow}$

$66 \%$

72(7)

anti/syn $>98: 2$

Scheme 14. Reduction/oxidation of 70(7). $\cdot^{34,35}$

Further investigation by Hruby led to the use of the thio-Claisen rearrangement as a key step to prepare novel optically active anti- $B$-substituted $\gamma, \delta$-unsaturated amino acids. ${ }^{36,37}$ The synthesis of desired compounds began with the thio-enolate, which was made by treatment of thioamide 75 with freshly prepared LDA in THF at $-78{ }^{\circ} \mathrm{C}$ and then the thio-enolate was alkylated at the sulfur position with allylic bromide (Scheme 15). In this highly selective method a bulky $C_{2}$-symmetric chiral auxiliary $(2 R, 5 R)-2,5$-diphenylpyrrolidine 73 was used. The thio-Claisen rearrangement was only possible after warming up to room temperature, and in some cases, it required even higher temperatures. The reactions were carried out with the six selected allylic bromides as summarized in Table $12 .^{36}$ The results indicated that the reactions proceeded with an excellent diastereoselectivity, and in most cases only the anti-products were obtained. When the size of the $\mathrm{R}^{3}$ substituent increased, there was a steric repulsion with the $\mathrm{Cbz}$ group, and this probably led to the decrease in diastereoselectivity (Table 12, entries $5 \& 6$ ). The authors explained this issue by modelling the transition states as proposed in Figure 8, of which 79a was preferred for steric reasons. 


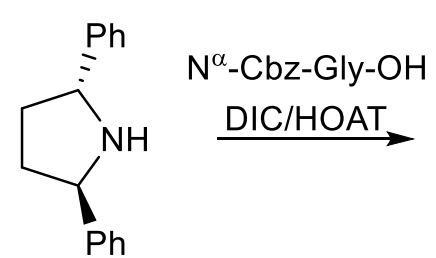

73

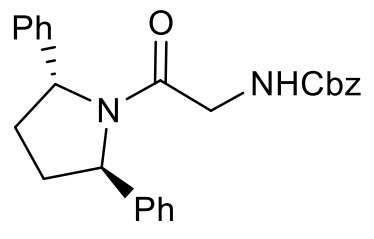

$74(90 \%)$<smiles>C[C@H](O[Mg])C(C)(C)C</smiles><smiles>[R]C(=C)C([R])([R])[C@H](N)C(=S)N1[C@H](c2ccccc2)CC[C@H]1c1ccccc1</smiles><smiles>[R]C(CC)=C([R])CBr</smiles>

78 major

warm up<smiles>[R2]C(=C)C([R])([R])[C@H](N)C(=S)N1[C@H](c2ccccc2)CC[C@H]1c1ccccc1</smiles>

Lawesson reagent

78' minor<smiles>[R]C([R])=C([R])CS/C(=C\N=C(O[Al])OCc1ccccc1)N1[C@H](c2ccccc2)CC[C@H]1c1ccccc1</smiles>

77<smiles>COc1ccc(P2(=S)SP(=S)(c3ccc(OC)cc3)S2)cc1</smiles>

$$
\begin{aligned}
& \text { 78(1) } R^{1}, R^{2}, R^{3}=H \\
& \text { 78(2) } R^{1}=H, R^{2}, R^{3}=M e \\
& \text { 78(3) } R^{1}=M e, R^{2}, R^{3}=H \\
& \text { 78(4) } R^{1}, R^{2}=H, R^{3}=M e \\
& \text { 78(5) } R^{1}, R^{2}=H, R^{3}=E t \\
& \text { 78(6) } R^{1}, R^{2}=H, R^{3}=P h
\end{aligned}
$$

\begin{tabular}{|c|c|c|c|c|c|}
\hline Entry & Allylic bromides & $\mathrm{T}\left({ }^{\circ} \mathrm{C}\right)$ & Yield $^{\mathrm{a}}(\%)$ & $d e(\%) 78: 78^{\prime b}$ & anti/syn $^{\mathrm{b}}$ \\
\hline 1 & & $-78 \rightarrow \mathrm{RT}$ & 82 & $>99$ & NA \\
\hline 2 & & $-78 \rightarrow$ reflux & 66 & $>99$ & NA \\
\hline 3 & & $-78 \rightarrow \mathrm{RT}$ & 74 & $>99$ & NA \\
\hline 4 & & $-78 \rightarrow 40$ & 78 & $>99$ & $>99: 1$ \\
\hline 5 & Et & $-78 \rightarrow 40$ & 76 & 78 & $>99: 1$ \\
\hline 6 & $\mathrm{Br}$ & $-78 \rightarrow \mathrm{RT}$ & 65 & 75 & $>73: 1$ \\
\hline
\end{tabular}

Scheme 15. Production of thio-enolate dianion and asymmetric thio-Claisen rearrangement. ${ }^{36}$

Table 12. Results of the asymmetric thio-Claisen rearrangement ${ }^{36}$

a Isolated yield of total isomers.

${ }^{\mathrm{b}}$ Determined by chiral HPLC. 


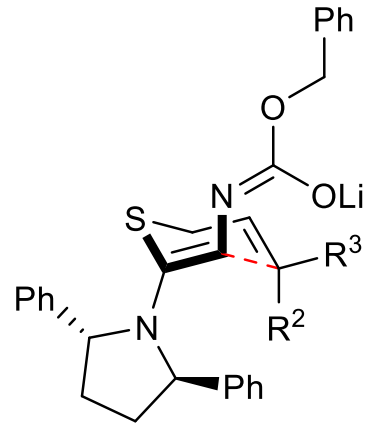

$79 a$

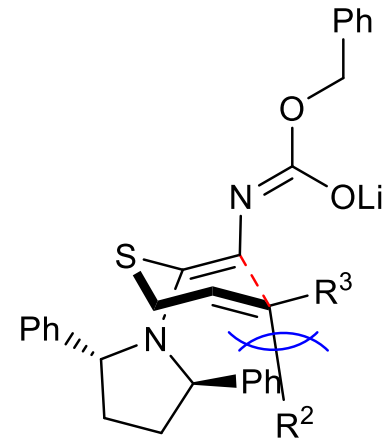

$79 b$

Figure 8. Proposed transition state models for thio-Claisen rearrangement. ${ }^{36}$

The step of removing of the chiral auxiliary consisted in one-pot alkylation-reduction-oxidation reaction. The amino thioamides were turned into amino acids with a minimal loss of the optical activity (Scheme 16).

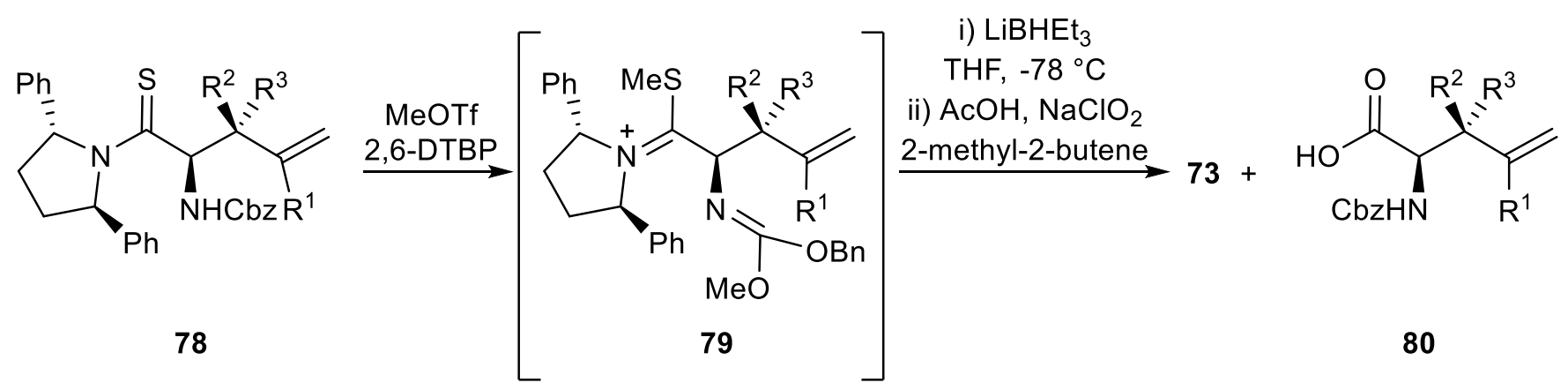

Scheme 16. Amino acids generation and chiral auxiliary recycle. ${ }^{36}$

Due to the fact that nature does not use the harsh reaction conditions presented in the above-described reactions (strong base LDA), Hruby et al. decided to develop a mild method to be able to obtain more structurally versatile amino acids. ${ }^{37}$ First, the use of thioamide was found to be crucial because the resulting thioiminium ion formation should increase the acidity of the $\alpha$ proton in comparison to the $\mathrm{NH}$ proton. Hence, one equivalent of a weak base was enough to deprotonate the $\alpha$ proton and trigger the thio-Claisen rearrangement. Secondly, they predicted that facilitating $\mathrm{C}-\mathrm{Br}$ bond breaking should improve allylation and rearrangement yields and hence a Friedel-Crafts catalyst $\mathrm{FeBr}_{3}$ was applied (Table 13). ${ }^{37}$ This mild reaction condition has given a chance to use the variety of functional group at the 6 -position. Also ester groups were successfully introduced (Table 13, entries 2 \& 3). Compounds $\mathbf{8 3 ( 2 )}$ and $\mathbf{8 3 ( 3 )}$ were synthesized as diastereopure products. It can be explained based on the transition state model $\mathbf{8 4 b}$ presented in the Figure 9. The ester carbonyl group would form a hydrogen bond with the $\alpha$-amino group, creating a second sixmembered ring to additional stabilize the transition state. ${ }^{37}$ 
Table 13. Results of new method of thio-Claisen rearrangement using Friedel-Crafts alkylation type reaction ${ }^{37}$

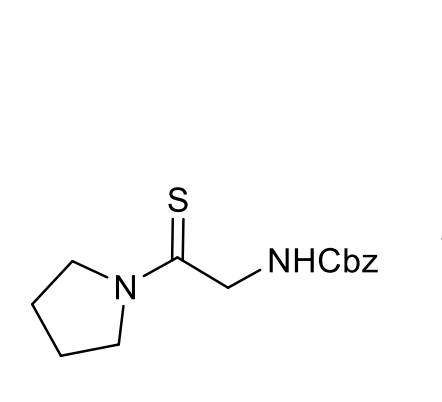

81<smiles>[R]C([R])=C([R])CBr</smiles>

76

20-40 mol \% $\mathrm{FeBr}_{3}$

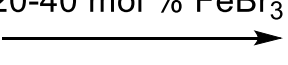

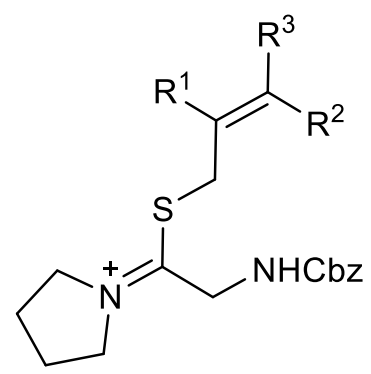

82<smiles>[R]C(=C)C([R])([R])[C@H](N)C(=S)N1CCCC1</smiles>

TEA, THF

-78 to $45^{\circ} \mathrm{C} \quad$ anti-83<smiles>[R]C(=C)C([R])([R3])[C@H](N)C(=S)N1CCCC1</smiles>

syn-83'

83(1) $\mathrm{R}^{1}=\mathrm{CO}_{2} \mathrm{Et}, \mathrm{R}^{2}, \mathrm{R}^{3}=\mathrm{H}$

83(2) $R^{1}, R^{2}=H, R^{3}=\mathrm{CO}_{2} \mathrm{Me}$

83(3) $R^{1}, R^{2}=H, R^{3}=\mathrm{CO}_{2} \mathrm{Et}$

\begin{tabular}{|c|c|c|c|}
\hline Entry & Allylic bromides & 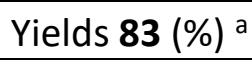 & anti/syn ${ }^{\mathrm{b}}$ \\
\hline 1 & $\mathrm{CO}_{2} \mathrm{Et}$ & 72 & NA \\
\hline 2 & $\mathrm{CO}_{2} \mathrm{Me}$ & 82 & $>49: 1$ \\
\hline 3 & $\mathrm{CO}_{2} \mathrm{Et}$ & 72 & $>49: 1$ \\
\hline
\end{tabular}

a Isolated yield of total isomers.

${ }^{\mathrm{b}}$ Determined by ${ }^{1} \mathrm{H}$ NMR.

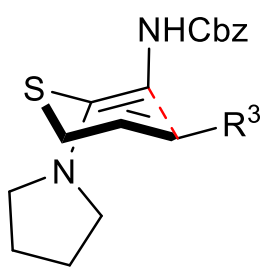

$84 a$

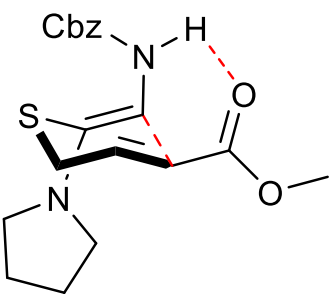

$84 b$

Figure 9. Proposed transition state models for thio-Claisen rearrangement. ${ }^{37}$

The last step was difficult due to the ester functional groups in the molecules. An oxidationiodolactonization-reduction pathway was used to generate the target molecules (Scheme 17). During these reactions little or no epimerization was observed. ${ }^{37}$ 
<smiles>[R]C(=C)C([R])([R])[C@@H](N)C(=S)N1CCCC1</smiles>

83

$$
\text { i) } m \text {-CPBA, DCM }
$$

$-78{ }^{\circ} \mathrm{C}$ to $\mathrm{RT}$

ii) $\mathrm{I}_{2}, \mathrm{THF} / \mathrm{H}_{2} \mathrm{O}, 4 \mathrm{~d}$

iii) $\mathrm{Zn}$ dust, $\mathrm{AcOH}, 70^{\circ} \mathrm{C}$

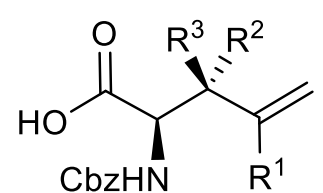

Scheme 17. Amino acids generation. ${ }^{37}$

This topic is especially important due to the multifunctionality of amino acids, especially those unsaturated, which are widely used as building blocks in peptidomimetics. Encouraged by previous positive results involving the highly asymmetric Eschenmoser-Claisen rearrangement ${ }^{35}$ and the thio-Claisen rearrangement ${ }^{36,37}$ Hruby et al. summarized their studies in a paper from $2012 .{ }^{38}$ In this approach, the authors also presented a combined method of applying Friedel-Crafts alkylation and the use of a three commercially available $C_{2}$-symmetric chiral auxiliary 88 a-c (Scheme 18 , Table 14).

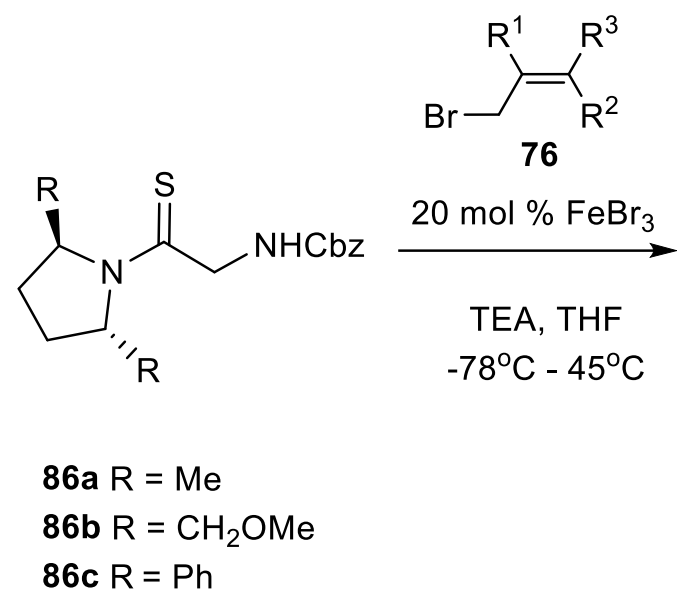

86c $R=P h$<smiles>[R]C(=C)C([R])([R])[C@H](N)C(=S)N1C([R])CC[C@H]1[R]</smiles>

$$
\begin{aligned}
& \text { 87a } \mathrm{R}=\mathrm{Me} \\
& \text { 87b } \mathrm{R}=\mathrm{CH}_{2} \mathrm{OMe} \\
& \text { 87c } \mathrm{R}=\mathrm{Ph}
\end{aligned}
$$

Scheme 18. Asymmetric thio-Claisen rearrangement with $C_{2}$-symmetric chiral auxiliaries. ${ }^{38}$

They noticed that the size of R group on the chiral auxiliary increased the diastereoselectivity. It was also observed that the carbonyl group in the allylic bromides resulted in the formation of the only one compound in the reaction, which confirmed their earlier findings based on the model $\mathbf{8 4 \mathbf { b }}$ of the transition state (Figure 9). When the $C=O$ group is at the $R^{1}$ position, $87 a(1), 87 b(1), 87 c(1)$, no bicyclic structure is formed and therefore no diastereoselectivity of the reaction is observed (Table 14). ${ }^{38}$ Due to the interest of the Hruby group in the solid-phase peptide synthesis, ${ }^{39}$ they also checked the influence of different protecting groups on diastereoselectivity. Except for Fmoc-protected amino acids, other usually applied N-protected amino acids were easily obtained with excellent optical purities. ${ }^{38}$ For this work, they also used a three-step oxidationiodolactonization-reduction method to convert the thioamides into the appropriate carboxylic acids. They also undertook the comparison of the ECR (Eschenmoser-Claisen rearrangement) with the TCR (thio-Claisen rearrangement) as summarized in Table 15. 
Table 14. Results of Asymmetric thio-Claisen rearrangement with $C_{2}$-symmetric chiral auxiliaries ${ }^{38}$

\begin{tabular}{|c|c|c|c|c|c|}
\hline Entry & Allylic bromides & Chiral auxiliary & Yield $^{\mathrm{a}}(\%)$ & anti/syn $^{\mathrm{b}}$ & $d e(\%)^{c}$ \\
\hline 1 & & $\mathrm{M \epsilon}$ & 64 & NA & $56^{e}$ \\
\hline 2 & & & 62 & $17: 1^{d}$ & $78^{d}$ \\
\hline 3 & $\mathrm{O}_{2} \mathrm{Me}$ & $88 a^{M e}$ & 86 & $99: 1^{e}$ & $99^{e}$ \\
\hline 4 & $\mathrm{O}_{2} \mathrm{Et}$ & & 83 & $99: 1^{e}$ & $99 \mathrm{e}$ \\
\hline 1 & & $\mathrm{leOH}_{2}$ & 54 & NA & $90^{\mathrm{e}}$ \\
\hline 2 & & & 52 & $30: 1^{e}$ & $88^{e}$ \\
\hline 3 & $\mathrm{O}_{2} \mathrm{Me}$ & " $\mathrm{CH}_{2} \mathrm{OMe}$ & 64 & $99: 1^{e}$ & $99 \mathrm{e}$ \\
\hline 4 & $\mathrm{O}_{2} \mathrm{Et}$ & $88 b$ & 65 & $99: 1^{\mathrm{e}}$ & 99 e \\
\hline 1 & & $\mathrm{Ph}$ & 60 & NA & $67^{e}$ \\
\hline 2 & & & 58 & $99: 1^{\mathrm{e}}$ & $91^{\mathrm{e}}$ \\
\hline 3 & $\mathrm{CO}_{2} \mathrm{Me}$ & $\mathrm{Ph}$ & 63 & $99: 1^{\mathrm{e}}$ & $99 \mathrm{e}$ \\
\hline 4 & $\mathrm{CO}_{2} \mathrm{Et}$ & $88 c$ & 70 & $99: 1^{e}$ & $99 \mathrm{e}$ \\
\hline
\end{tabular}

asolated yield of total isomers.

${ }^{\mathrm{b}}$ Anti: $2 S, 3 S$ and $2 R, 3 R$, Syn: $2 S, 3 R$ and $2 R, 3 S$.

${ }^{c}$ Diastereomeric excess between two anti isomers: anti major $2 S, 3 S$; anti minor $2 R, 3 R$.

d Determined by weight.

e Determined by chiral HPLC. 
Table 15. Results of comparing ECR and TCR diastereoselectivities ${ }^{38}$

Yield (\%)

a Isolated yield of total isomers.

${ }^{b}$ Anti: $2 S, 3 S$ and $2 R, 3 R$, Syn: $2 S, 3 R$ and $2 R, 3 S$.

${ }^{c}$ Diastereomeric excess between two anti isomers: anti major $2 S, 3 S$; anti minor $2 R, 3 R$.

d Determined by chiral HPLC.

e Inseparable diastereomeric mixtures.

${ }^{f}$ Results from previous publications.

In summary, the thio-Claisen reaction using catalytic $\mathrm{FeBr}_{3}$ in the alkylation step may be a commonly used method. The mild reaction conditions make it suitable for compounds with various substituents as well as protecting groups.

\section{Application of Claisen Rearrangement to the Synthesis of Fluorine-containing $\gamma, \delta$ - Unsaturated Amino Acids}

In this review we would like also to show that there are several examples of the use of Claisen rearrangement to obtain fluorine-containing amino acids. Fluorine is not one of the favourite elements that nature applies to construct organic matter. However, it is such a valuable construction material for the synthesis of biologically active compounds that the chemists use the available tools to receive organofluorine compounds. ${ }^{40,41}$ The 
direct fluorination and the methods employing fluorinated building blocks are knowable ways for their preparation. ${ }^{42,43}$ These intermolecular reactions are multistage and involve quite drastic reaction conditions. The intramolecular rearrangement reaction such as Claisen rearrangement or related [3,3]-sigmatropic rearrangements might be an interesting alternative route. Rearrangement reactions belong to the most often used transformations, especially for the synthesis of fluorine-containing unsaturated amino acids. This class of non-proteinogenic amino acids is particularly important because their non-fluorinated counterparts have relevant features: act as a potent inhibitors of enzymes ${ }^{44}$ or participate in the synthesis of peptidomimetics or peptides. $^{45}$

In 1998 Percy and Prime applied first the Kazmaier's methodology to the synthesis of fluorinated compounds. ${ }^{46}$ The $\mathrm{N}$-protected $\gamma, \gamma$-difluorinated glycinate esters 93 were rearranged with $\mathrm{ZnCl}_{2}$ to yield 6,6 difluoro- $\alpha$-aminio acids 94 (Scheme 19). The rearranged acid was the only product of the reaction, what was revealed by both ${ }^{19} \mathrm{~F}$ and ${ }^{1} \mathrm{H}$ NMR spectroscopy.

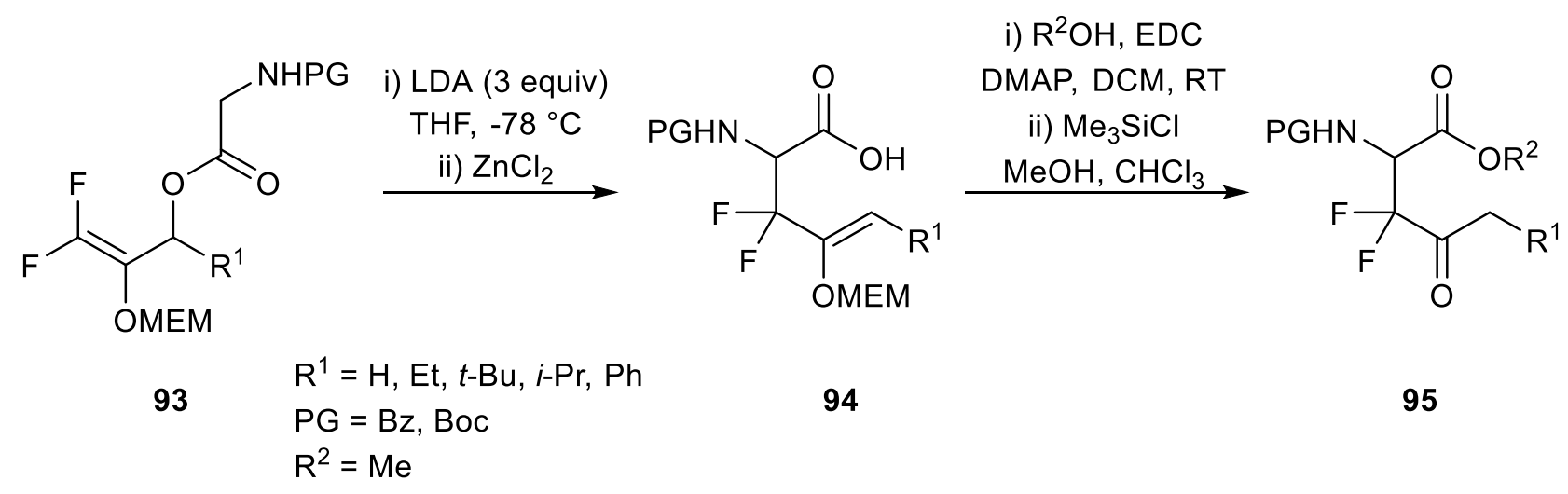

Scheme 19. A short route to the 6,6 -difluoro- $\alpha$-aminio acids via chelated [3,3]-rearrangement. ${ }^{46}$

The optically active 6 -fluoroalkylated $\gamma, \delta$-unsaturated amino acids were synthesized by sequential $\mathrm{Pd}$ catalyzed allylic substitution and Ireland-Claisen rearrangement by Konno et al. ${ }^{47}$ The glycine allyl ester 98 was generated readily from the mesylate $\mathbf{9 7}$ by the Pd-catalyzed allylic substitution reaction presented below (Scheme 20). ${ }^{48}$ 


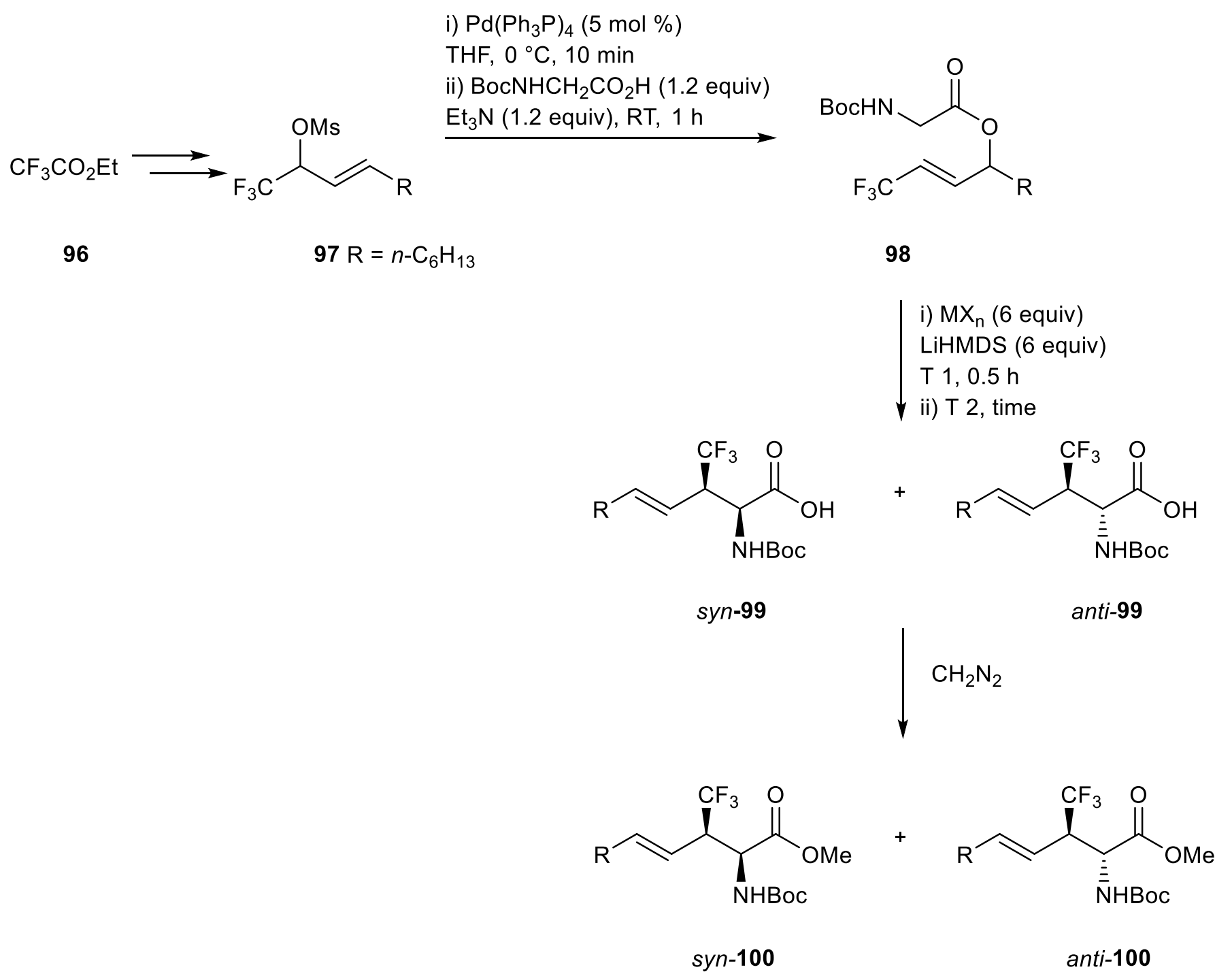

Scheme 20. The combination reactions of Pd-catalyzed allylic substitution and Ireland-Claisen rearrangement. ${ }^{47}$

Experiment showed that the allylic substitution reaction of fluorinated allyl mesylate with $N$-Boc glycine gave neither the regioisomer 101, the stereoisomer 102 nor the allylamine derivative 103 (Figure 10). ${ }^{47}$

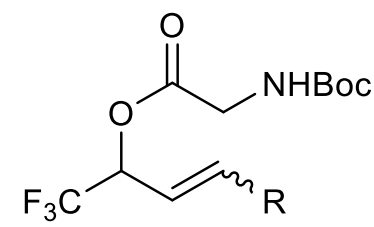

101<smiles>[R]C(/C=C\C(=O)O)OC(=O)CNC(=O)O</smiles>

102<smiles>[R]C(C=CC(F)(F)F)[N+](=O)[O-]</smiles>

103

Figure 10. The feasible products of the palladium-catalyzed allylic substitution reaction. ${ }^{47}$

The next step, the Ireland-Claisen rearrangement required investigation (Scheme 20, Table 16). Bartlett and Barstow reported in 1982 that non-fluorinated glycine crotyl ester underwent Ireland-Claisen rearrangement stereoselectively and with good yield. ${ }^{49}$ Herein, the products syn-99 and anti-99 were formed 
as a diastereomeric mixture in a $62: 38$ ratio and in unsatisfactory $48 \%$ yield (Table 16 , entry 1 ). Stirring the mixture heated at reflux for $6 \mathrm{~h}$ led to a marked increase of the yield (94\%) but the stereoselectivity remained moderate (Table 16, entry 3). The reaction without $\mathrm{TMSCl}$ gave excellent diastereoselectivity, but did not lead to an acceptable yield (Table 16 , entry 4 ).

Table 16. Investigation of the reaction conditions ${ }^{47}$

\begin{tabular}{cccccccc}
\hline Entry & $\mathrm{MX}$ & $\begin{array}{c}\mathrm{T} 1 \\
\left({ }^{\circ} \mathrm{C}\right)\end{array}$ & $\begin{array}{c}\mathrm{T} 2 \\
\left({ }^{\circ} \mathrm{C}\right)\end{array}$ & $\begin{array}{c}\text { Time } \\
(\mathrm{h})\end{array}$ & $\begin{array}{c}\text { Yield of 99 } \\
(\%)^{\mathrm{a}}\end{array}$ & $\begin{array}{c}\text { Yield of 98 } \\
(\%)^{\mathrm{a}}\end{array}$ & $\begin{array}{c}\text { Diastereomeric } \\
\text { ratio }\end{array}$ \\
\hline 1 & $\mathrm{TMSCl}$ & -78 & $\mathrm{RT}$ & 6 & 48 & 44 & $62: 38$ \\
2 & $\mathrm{TMSCl}$ & -78 & $\mathrm{RT}$ & 20 & 45 & 55 & $54: 46$ \\
3 & $\mathrm{TMSCl}$ & -78 & reflux & 6 & 94 & 2 & $73: 27$ \\
4 & - & -78 & $\mathrm{RT}$ & 20 & 49 & 23 & $100: 0$ \\
5 & $\mathrm{TMSCl}$ & 0 & $\mathrm{RT}$ & 20 & 62 & 32 & $96: 4$ \\
6 & $\mathrm{TMSCl}$ & 0 & reflux & 6 & 84 & 9 & $91: 9$ \\
7 & $\mathrm{TMSCl}$ & 0 & reflux & 15 & 84 & 11 & $90: 10$ \\
$8^{\mathrm{b}}$ & $\mathrm{TMSCl}$ & 0 & reflux & 6 & 79 & 4 & $94: 6$ \\
9 & $\mathrm{ZnCl} 2$ & 0 & reflux & 6 & 82 & 14 & $100: 0$ \\
10 & $\mathrm{ZnCl}_{2} \bullet \mathrm{TMEDA}^{2}$ & 0 & reflux & 6 & 71 & 22 & $100: 0$ \\
\hline
\end{tabular}

${ }^{\text {a }}$ Determined by ${ }^{19} \mathrm{~F}$ NMR.

${ }^{\mathrm{b}}$ Glycine was used instead of Boc-glycine.

Kazmaier et al., ${ }^{10}$ findings that the bidentate chelation in the enolate by using $\mathrm{ZnCl}_{2}$ brings a marked enhancement of thermal stability and that the Ireland-Claisen rearrangement proceeds stereoselectively (Table 16, entry 9) can be represented by the mechanism depicted in Scheme 21. Treatment of the glycine allyl ester with $\mathrm{ZnCl}_{2}$ gave in the stereoselective manner the (Z)-enolate $\mathbf{9 8}$ (Int-A). A stereoselective Ireland-Claisen rearrangement via the energetically stable six-membered cyclic transition state 98 (Int-B), where the $R$ group takes the equatorial position, resulted in the desired 8 -trifluoromethylated amino acid 99 with $(2 S, 3 R)$ configuration. ${ }^{47}$<smiles>[R]C(/C=C/C(F)(F)F)O[C@@H]([R])/C=C/C(F)(F)C(=O)N1[Z17]OC(O[R16](=O)c2ccccc2)=C1</smiles>

98

98 Int-A

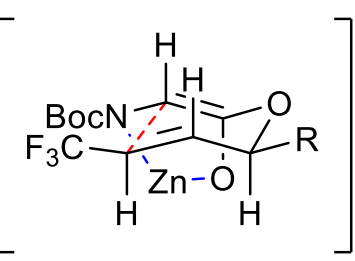

98 Int-B

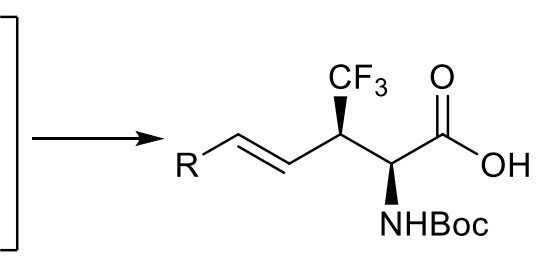

99

Scheme 21. The mechanism of the Ireland-Claisen rearrangement. ${ }^{47}$

The rearranged product 100 was then stirred for several hours at $0{ }^{\circ} \mathrm{C}$ with TFA and DCM (50:50 v:v) to deprotect the NH group. The TFA salt 104 was treated with Mosher's acid chloride and DMAP to give the MTPA-amide 105 with 92\% diastereomeric access (Scheme 22). 


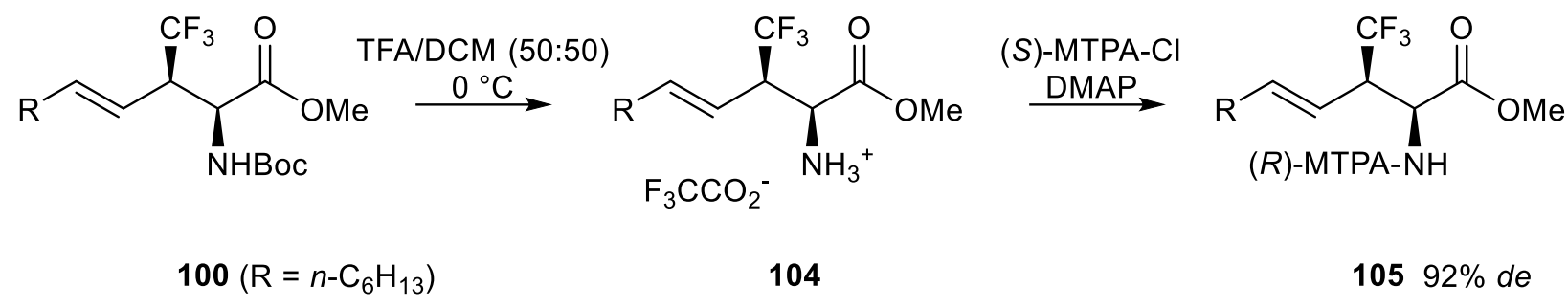

Scheme 22. Removing of the Boc group.

The above presented method also served as a good way for the preparation of chiral amino acids with other fluoroalkylated groups $\left(-\mathrm{CF}_{2} \mathrm{H},-\mathrm{CF}_{2} \mathrm{CF}_{3}\right)$ at the 6 position. ${ }^{47}$

The synthesis of $\gamma$-fluoro- $\gamma, \delta$-unsaturated $\alpha$-amino acids was described by Haufe research group in $2005 .{ }^{50}$ The Kazmaier variant of the Ireland-Claisen rearrangement with minor modifications constituted an essential stage of this approach. Fluorinated allylic esters of glycine $\mathbf{1 0 7}$ and $(R, S)$-alanine $\mathbf{1 0 8}$ were prepared according to the method earlier described independently by two groups ${ }^{51-52}$ (Table 17). This procedure gave the best results with Boc-amino acids (esters 109 and 110). The fluoroallyl alcohols used in this reaction were prepared via allylic hydroxylation of vinyl fluorides. ${ }^{53}$

Table 17. Synthesis of amino acid 2-fluoroallylic esters $\mathbf{1 0 9 - 1 1 2} \mathbf{1 0}^{50}$<smiles>[R]C=C(F)C([R])O</smiles><smiles>[R]/C=C(/F)C([R])OC(=O)C([R])NCCN</smiles>

106 107,108

109-112

\begin{tabular}{|c|c|c|c|c|c|}
\hline Entry & $\mathrm{R}^{1}$ & $R^{2}$ & $R^{3}$ & PG & Yields (\%) \\
\hline 1 & $\mathrm{C}_{3} \mathrm{H}_{7}$ & $\mathrm{H}$ & $\mathrm{H}$ & Boc & 109a (80) \\
\hline 2 & $\mathrm{C}_{3} \mathrm{H}_{7}$ & $\mathrm{H}$ & Me & Boc & 110a (69) \\
\hline 3 & $\mathrm{C}_{7} \mathrm{H}_{15}$ & $\mathrm{H}$ & $\mathrm{H}$ & Boc & 109b (94) \\
\hline 4 & $\mathrm{C}_{7} \mathrm{H}_{15}$ & $\mathrm{H}$ & $\mathrm{Me}$ & Boc & 110b (96) \\
\hline 5 & $\mathrm{C}_{13} \mathrm{H}_{27}$ & $\mathrm{H}$ & $\mathrm{H}$ & Boc & 109c (92) \\
\hline 6 & $\mathrm{C}_{13} \mathrm{H}_{27}$ & $\mathrm{H}$ & Me & Boc & $110 c(100)$ \\
\hline 7 & $\mathrm{H}$ & $\mathrm{C}_{7} \mathrm{H}_{15}$ & $\mathrm{H}$ & Boc & 110d (97) \\
\hline 8 & $\mathrm{H}$ & $\mathrm{H}$ & $\mathrm{H}$ & Boc & 110 e (96) \\
\hline 9 & $\mathrm{H}$ & $\mathrm{H}$ & Me & Boc & $110 f(88)$ \\
\hline 10 & $\mathrm{C}_{3} \mathrm{H}_{7}$ & $\mathrm{H}$ & $\mathrm{H}$ & TFA & $111 a(33)$ \\
\hline 11 & $\mathrm{C}_{7} \mathrm{H}_{15}$ & $\mathrm{H}$ & $\mathrm{H}$ & TFA & 111b (54) \\
\hline 12 & $\mathrm{C}_{13} \mathrm{H}_{27}$ & $\mathrm{H}$ & $\mathrm{H}$ & TFA & 111c (51) \\
\hline 13 & $\mathrm{H}$ & $\mathrm{H}$ & $\mathrm{H}$ & TFA & 111e (57) \\
\hline 14 & $\mathrm{C}_{3} \mathrm{H}_{7}$ & $\mathrm{H}$ & Me & TFA & $112 a(29)$ \\
\hline 15 & $\mathrm{C}_{7} \mathrm{H}_{15}$ & $\mathrm{H}$ & Me & TFA & $112 b(50)$ \\
\hline 16 & $\mathrm{C}_{13} \mathrm{H}_{27}$ & $\mathrm{H}$ & Me & TFA & $112 c(26)$ \\
\hline 17 & $\mathrm{H}$ & $\mathrm{H}$ & $\mathrm{Me}$ & TFA & $112 f(35)$ \\
\hline
\end{tabular}


The rearrangement of the $\gamma$-fluoro-amino acid esters, obtained from Boc-glycine, failed under conditions described by Kazmaier. The substrates were either recovered almost quantitatively or the esters were hydrolyzed. However, an approach using $\mathrm{Et}_{2} \mathrm{O}$ instead of THF enabled the rearrangement of the Boc-glycine esters 109a-c and the $\gamma$-fluoro- $\gamma, \delta$-unsaturated $\alpha$-amino acids $113 a-c$ were obtained (Table 18, entries 1-3). Worthy of note was that increasing the steric demand of the $\mathrm{R}^{1}$ substituent impacted the degree of rearrangement. The reaction of compound $\mathbf{1 1 3 d}$ with $R^{1}=H$ failed (Table 18 , entries 4 \& 5)..$^{50}$

Table 18. Results of ester enolate Claisen rearrangement ${ }^{50}$

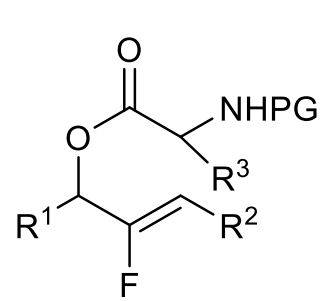

109a-e
1) i) LDA (2.5 equiv.), $\mathrm{Et}_{2} \mathrm{O},-78^{\circ} \mathrm{C}$

ii) $\mathrm{ZnCl}_{2}$ (1.2 equiv.), $-78^{\circ} \mathrm{C}$ to $\mathrm{RT}$

iii) $\mathrm{H}_{2} \mathrm{O}$

2) i) $\mathrm{LiHMDS}, \mathrm{Et}_{2} \mathrm{O},-78^{\circ} \mathrm{C}$

ii) $\mathrm{ZnCl}_{2},-78{ }^{\circ} \mathrm{C}$ to $\mathrm{RT}$

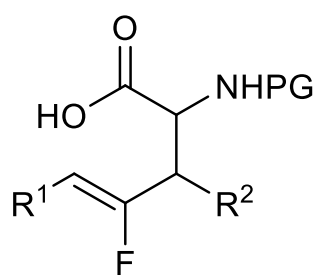

113a-e

\begin{tabular}{ccccccc}
\hline Entry & Products & $\mathrm{R}^{1}$ & $\mathrm{R}^{2}$ & $\mathrm{R}^{3}$ & $\begin{array}{c}\text { Yield (\%) } \\
\text { PG = Boc }\end{array}$ & $\begin{array}{c}\text { Yield (\%) } \\
\mathrm{PG}^{-} \mathrm{TFA}^{\mathrm{a}}\end{array}$ \\
\hline 1 & $\mathbf{1 1 3 a}$ & $\mathrm{C}_{3} \mathrm{H}_{7}$ & $\mathrm{H}$ & $\mathrm{H}$ & 36 & 41 \\
2 & $\mathbf{1 1 3 b}$ & $\mathrm{C}_{7} \mathrm{H}_{15}$ & $\mathrm{H}$ & $\mathrm{H}$ & 64 & 45 \\
3 & $\mathbf{1 1 3 c}$ & $\mathrm{C}_{13} \mathrm{H}_{27}$ & $\mathrm{H}$ & $\mathrm{H}$ & 39 & 41 \\
4 & $\mathbf{1 1 3 d ^ { b }}$ & $\mathrm{H}$ & Alkyl or H & Alkyl or H & 0 & 0 \\
5 & $\mathbf{1 1 3 e}^{\mathrm{b}}$ & Alkyl or H & Alkyl or H & Alkyl or H & 0 & 0 \\
\hline
\end{tabular}

${ }^{a} \mathrm{LiHMDS}_{\mathrm{Et}} \mathrm{O}$

${ }^{\mathrm{b}}$ Starting materials were recovered

Presumably, the esters $\mathbf{1 1 0}$ of a racemic alanine, valine and phenylglycine with $\mathrm{R}^{3} \neq \mathrm{H}$ did not rearrange because of steric reasons. These problems did not occur for non-fluorinated allylic esters tested by Kazmaier. However, Percy et al. described a similar case in Johnson-Claisen rearrangement of $b$-chloro- $\nu$-fluoroallylic esters. ${ }^{54}$ This may suggest the fluorine atom impact, which was investigated using the reaction shown below (Scheme 23). It seems preferable to deprotonate the allyl position of $b$ to a fluorine substituent. The rearrangement of compounds with $\mathrm{R}^{1}=\mathrm{H}$ probably failed for this reason. The use of lithium hexamethyldisilyl amide (LiHMDS) was expected to avoid this problem.

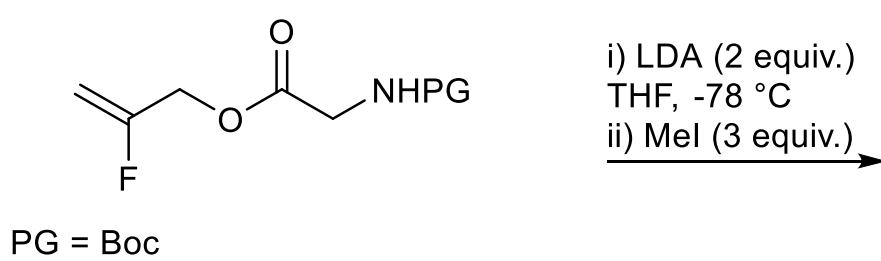

114

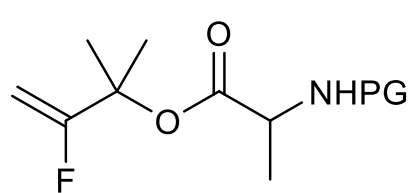

115 and other products

Scheme 23. Fluorine atom impact on deprotonation. ${ }^{50}$ 
The deprotection reactions were accomplished under salt-free conditions (Scheme 24).<smiles>[R]C=C(F)CC(NC(=O)O)C(=O)O</smiles>

113

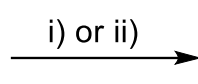<smiles>[R]C=C(F)CC(N)C(=O)O</smiles>

\section{Reaction conditions}
i) TFA, $\mathrm{Me}_{2} \mathrm{~S}, \mathrm{RT}, 1 \mathrm{~h}$ $P G=B o c, R=\mathrm{C}_{7} \mathrm{H}_{15}$
ii) $\mathrm{NH}_{3}, \mathrm{MeOH}, \mathrm{RT}, 3$ days $P G=T F A, R=$ alk

Scheme 24. Deprotection of $\gamma$-fluoro- $\gamma, \delta$-unsaturated $\alpha$-amino acids derivative. ${ }^{50}$

The presented research shows that there must be a balanced combination of steric and electronic effects of substituents in the $\alpha$ position to the carbonyl group and $b$ to the fluorine atom to enable ester enolate Claisen rearrangement of the fluorinated esters of amino acids. ${ }^{50}$

Chen et al. proposed a Claisen rearrangement and iodolactamization sequence leading to the 4,4-difluoro3,3-dimethylproline derivative $\mathbf{1 2 6} \mathbf{6 5}^{55,56}$ (Scheme 25 ), whose $(S$ )-enantiomer is a key building block for a number of second-generation HIV protease inhibitors. ${ }^{57}$

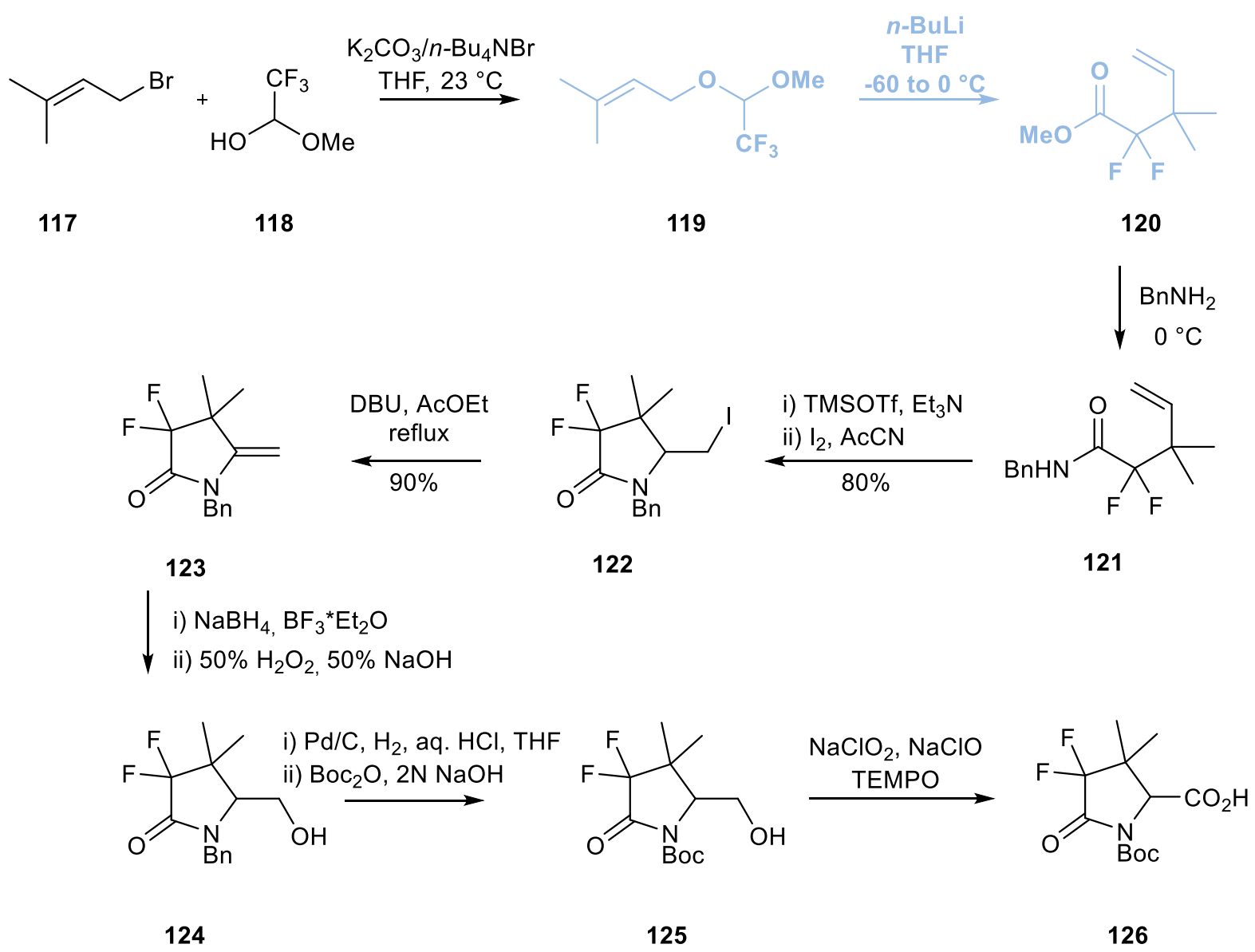

Scheme 25. Synthesis of 4,4-difluoro-3,3-dimethylproline derivative $126 .{ }^{56}$ 
The application of a Claisen rearrangement to introduce the difluoro moiety into the molecule was a valuable alternative (Scheme 26) to the low yielding original synthesis, which required expensive and dangerous reagents (DAST and Deoxo-Fluor). ${ }^{58}$

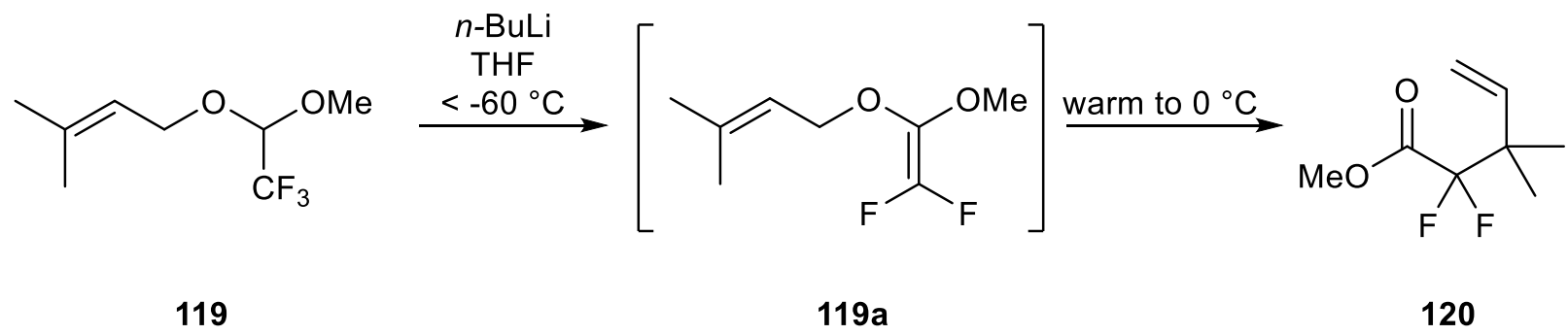

Scheme 26. Key step of the 4,4-difluoro-3,3-dimethylproline derivative synthesis.

The preparation of non-natural and/or fluorine containing amino acids and their precursors can be a considerable effort for chemists, but their significant application primarily for medicine and pharmacy makes researchers take up this challenge. The use of a Claisen rearrangement and its variants may, due to the fact that it is an intramolecular reaction, enable the synthesis of these compounds, as presented in this paper.

\section{Conclusions}

Considering the quantity and quality of articles over the last 25-years which describe research on the Claisen rearrangement, we can safely assume that this topic will undergo further development. The protocol finds wide use in the synthesis of optically pure compounds needed as building blocks to prepare key compounds in bioorganic and medical chemistry. The versatility of the Claisen rearrangement was further demonstrated via the synthesis of fluorinated $y, \delta$-unsaturated amino acids that highlighted the significant influence of the fluorine atom on the properties of biomolecules.

\section{Acknowledgements}

The Authors would like to thank Prof. Zbigniew Czarnocki for long lasting cooperation.

\section{References}

1. Claisen, L. Ber. Dtsch. Chem. Ges. 1912, 45, 3157.

https://doi.org/10.1002/cber.19120450348

2. Majumdar, K. C.; Nandi, R. K. Tetrahedron 2013, 69, 6921.

https://doi.org/10.1016/j.tet.2013.06.003.

3. Kübel, B.; Höfle, G.; Steglich, W. Angew. Chem. Int. Ed. 1975, 14, 58.

https://doi.org/10.1002/anie.197500581

4. Bartlett, P. A.; Barstow, J. F. J. Org. Chem. 1982, 47, 3933. 
https://doi.org/10.1021/jo00141a024

5. Liu, Z.; Mehta, S. J.; Hruby, V. J. Org. Prep. Proced. Int. 2012, 44, 222.

https://doi.org/10.1080/00304948.2012.676507

6. Kotha, S.; Meshram, M. Chem. - Asian J. 2018, 13, 1758.

https://doi.org/10.1002/asia.201800613

7. Moiola, M.; Memeo, M. G.; Quadrelli, P. Molecules 2019, 24, 3654.

https://doi.org/10.3390/molecules24203654

8. Kazmaier, U. Amino Acids 1996, 11, 283.

https://doi.org/10.1007/BF00807937

9. Kazmaier, U. Liebigs Ann./Recl. 1997, 1997, 285.

https://doi.org/10.1002/ilac.199719970203

10. Kazmaier, U. Angew. Chem. Int. Ed. Engl. 1994, 33, 998.

https://doi.org/10.1002/anie.199409981

11. Kiefer, A.; Bader, C. D.; Held, J.; Esser, A.; Rybniker, J.; Empting, M.; Müller, R.; Kazmaier, U. Chem. - Eur. J. 2019, 25, 8894.

https://doi.org/10.1002/chem.201901640

12. Quirin, C.; Kazmaier, U. Eur. J. Org. Chem. 2009, 2009, 371.

https://doi.org/10.1002/ejoc.200800890

13. Kazmaier, U. Tetrahedron Lett. 1996, 37, 5351.

https://doi.org/10.1016/0040-4039(96)01104-5

14. Kazmaier, U.; Zumpe, F. L. Angew. Chem. Int. Ed. 1999, 38, 1468.

https://doi.org/10.1002/(SICI)1521-3773(19990517)38:10<1468::AID-ANIE1468>3.0.CO;2-O.

15. Kazmaier, U.; Maier, S. J. Chem. Soc., Chem. Commun. 1995, 1991.

https://doi.org/10.1039/C39950001991

16. Quirin, C.; Kazmaier, U. Synthesis 2009, 2009, 1725.

https://doi.org/10.1055/s-0028-1088121

17. Kazmaier, U.; Maier, S. Chem. Commun. 1998, 2535.

https://doi.org/10.1039/A805784B

18. Becker, D.; Kazmaier, U. J. Org. Chem. 2013, 78, 59.

https://doi.org/10.1021/jo301693d

19. Jeon, H.; Chung, Y.; Kim, S. J. Org. Chem. 2019, 84, 8080.

https://doi.org/10.1021/acs.joc.9b00933

20. Mohamed, M.; Brook, M. A. Tetrahedron Lett. 2001, 42, 191.

https://doi.org/10.1016/S0040-4039(00)01962-6

21. Kazmaier, U.; Krebs, A. Angew. Chem. Int. Ed. Engl. 1995, 34, 2012.

https://doi.org/10.1002/anie.199520121

22. Kazmaier, U.; Mues, H.; Krebs, A. Chem. - Eur. J. 2002, 8, 1850.

https://doi.org/10.1002/1521-3765(20020415)8:8<1850::AID-CHEM1850>3.0.CO;2-Q

23. Kazmaier, U.; Krebs, A. Tetrahedron Lett. 1999, 40, 479.

https://doi.org/10.1016/S0040-4039(98)02486-1

24. Bakke, M.; Ohta, H.; Kazmaier, U.; Sugai, T. Synthesis 1999, 1999, 1671.

https://doi.org/10.1055/s-1999-3565

25. Mues, H.; Kazmaier, U. Synthesis 2001, 2001, 487.

https://doi.org/10.1055/s-2001-11451 
26. Kazmaier, U.; Schauß, D.; Pohlman, M.; Raddatz, S. Synthesis 2000, 2000, 914. https://doi.org/10.1055/s-2000-6293

27. Kazmaier, U.; Schauß, D.; Raddatz, S.; Pohlman, M. Chem. - Eur. J. 2001, 7, 456. https://doi.org/10.1002/1521-3765(20010119)7:2<456::AID-CHEM456>3.0.CO;2-A

28. Mizota, I.; Tanaka, K.; Shimizu, M. Tetrahedron Lett. 2012, 53, 1847. https://doi.org/10.1016/j.tetlet.2012.01.133

29. Reetz, M. T. Chem. Rev. 1999, 99, 1121. https://doi.org/10.1021/cr980417b

30. Karjalainen, O. K.; Koskinen, A. M. P. Org. Biomol. Chem. 2012, 10, 4311. https://doi.org/10.1039/C2OB25357G

31. Ricard, S.; Sanapo, G. F.; Rahem, N.; Daoust, B. J. Org. Chem. 2016, 81, 5066. https://doi.org/10.1021/acs.joc.6b00512

32. Gu, X.; Ying, J.; Min, B.; Cain, J. P.; Davis, P.; Willey, P.; Navratilova, E.; Yamamura, H. I.; Porreca, F.; Hruby, V. J. Biopolymers 2005, 80, 151.

https://doi.org/10.1002/bip.20208

33. Rutjes, F. P. J. T.; Wolf, L. B.; Schoemaker, H. E. J. Chem. Soc., Perkin Trans. 1 2000, 4197. https://doi.org/10.1039/B001538P

34. Qu, H.; Gu, X.; Min, B. J.; Liu, Z.; Hruby, V. J. Org. Lett. 2006, 8, 4215. https://doi.org/10.1021/ol061414l

35. Qu, H.; Gu, X.; Liu, Z.; Min, B. J.; Hruby, V. J. Org. Lett. 2007, 9, 3997. https://doi.org/10.1021/ol701704h

36. Liu, Z.; Qu, H.; Gu, X.; Min, B. J.; Nyberg, J.; Hruby, V. J. Org. Lett. 2008, 10, 4105. https://doi.org/10.1021/ol801657q

37. Liu, Z.; Qu, H.; Gu, X.; Lee, K.-S.; Grossman, B.; Kumirov, V. K.; Hruby, V. J. Tetrahedron Lett. 2010, 51 , 3518. https://doi.org/10.1016/j.tetlet.2010.04.102

38. Liu, Z.; Mehta, S. J.; Lee, K.-S.; Grossman, B.; Qu, H.; Gu, X.; Nichol, G. S.; Hruby, V. J. J. Org. Chem. 2012, $77,1289$.

https://doi.org/10.1021/jo201753q

39. Mollica, A.; Guardiani, G.; Davis, P.; Ma, S.-W.; Porreca, F.; Lai, J.; Mannina, L.; Sobolev, A. P.; Hruby, V. J. J. Med. Chem. 2007, 50, 3138. https://doi.org/10.1021/jm061048b

40. Cytlak, T.; Kaźmierczak, M.; Skibińska, M.; Koroniak, H. Phosphorus, Sulfur Silicon Relat. Elem. 2017, 192, 602.

https://doi.org/10.1080/10426507.2017.1287706

41. Bilska-Markowska, M.; Szwajca, A.; Marciniak, B. J. Fluorine Chem. 2019, 227, 109364. https://doi.org/10.1016/i.jfluchem.2019.109364

42. Moschner, J.; Stulberg, V.; Fernandes, R.; Huhmann, S.; Leppkes, J.; Koksch, B. Chem. Rev. 2019, 119, 10718.

https://doi.org/10.1021/acs.chemrev.9b00024

43. Zhang, X.; Ni, W.; van der Donk, W. A. J. Org. Chem. 2005, 70, 6685. https://doi.org/10.1021/jo0511820

44. Tsubotani, S.; Funabashi, Y.; Takamoto, M.; Hakoda, S.; Harada, S. Tetrahedron 1991, $47,8079$. https://doi.org/10.1016/S0040-4020(01)91004-X

45. Kurokawa, N.; Ohfune, Y. J. Am. Chem. Soc. 1986, 108, 6041. 
https://doi.org/10.1021/ja00279a064

46. Percy, J. M.; Prime, M. E.; Broadhurst, M. J. J. Org. Chem. 1998, 63, 8049.

https://doi.org/10.1021/jo981119h.

47. Konno, T.; Daitoh, T.; Ishihara, T.; Yamanaka, H. Tetrahedron: Asymmetry 2001, 12, 2743. https://doi.org/10.1016/S0957-4166(01)00485-2

48. Konno, T.; Ishihara, T.; Yamanaka, H. Tetrahedron Lett. 2000, 41, 8467. https://doi.org/10.1016/S0040-4039(00)01485-4

49. Bartlett, P. A.; Tanzella, D. J.; Barstow, J. F. J. Org. Chem. 1982, 47, 3941. https://doi.org/10.1021/jo00141a025

50. Tranel, F.; Fröhlich, R.; Haufe, G. J. Fluorine Chem. 2005, 126, 555. https://doi.org/10.1016/i.jfluchem.2004.12.009

51. Neises, B.; Steglich, W. Angew. Chem. Int. Ed. 1978, 17, 522. https://doi.org/10.1002/anie.197805221.

52. Hassner, A.; Alexanian, V. Tetrahedron Lett. 1978, 19, 4475. https://doi.org/10.1016/S0040-4039(01)95256-6.

53. Ernet, T.; Haufe, G. Synthesis 1997, 1997, 953. https://doi.org/10.1055/s-1997-1279.

54. Brown, S. J.; Corr, S.; Percy, J. M. Tetrahedron Lett. 2000, 41, 5269. https://doi.org/10.1016/S0040-4039(00)00804-2.

55. Chen, L.; Kim, Y. M.; Kucera, D. J.; Harrison, K. E.; Bahmanyar, S.; Scott, J. M.; Yazbeck, D. J. Org. Chem. 2006, 71, 5468. https://doi.org/10.1021/jo060057p.

56. Qiu, X.-L.; Qing, F.-L. Eur. J. Org. Chem. 2011, 2011, 3261. https://doi.org/10.1002/ejoc.201100032.

57. Kucera, D. J.; Scott, R. W. U.S. Patent Appl. 20040204591, 2004.

58. Canan-Koch, S. S.; Alexander, T. N.; Barvian, M.; Bolton, G.; Boyer, F. E.; Burke, B. J.; Holler, T.; Jewell, T. M.; Prasad, J. V.; Kucera, D. J.; Linton, M. A.; Machak, J.; Mitchell, L. J.; Murphy, S. T.; Reich, S. H.; Skalitzky, D. J.; Tatlock, J. H.; Varney, M. D.; Virgil, S. C.; Webber, S. E.; Worland, S. T.; Melnick, M. PCT Int. Appl. WO $2002100844,2002$.

\section{Authors' Biographies}

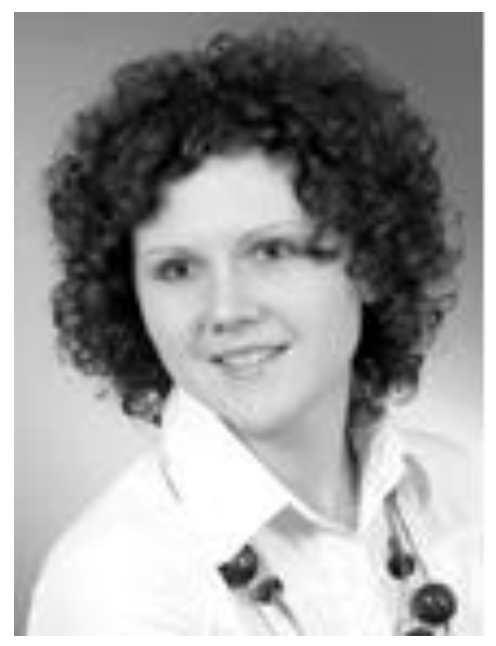


Dr Monika Bilska-Markowska is Assistant Professor in the Department of Synthesis and Structure of Organic Compounds, Faculty of Chemistry, at Adam Mickiewicz University in Poznań. She graduated her studies in 2008 at the Faculty of Chemistry of Adam Mickiewicz University, where she also received her Ph.D. in 2012 under the supervision of Professor Henryk Koroniak. As a Ph.D. student she joined the group of Professor Günter Haufe at Westfälische Wilhelms-Universität in Münster. Her research interests are related to the organofluorine chemistry, especially fluorinated carbohydrates. It focuses not only on the synthesis of designated compounds, but also on the development of reaction mechanisms for introducing a fluorine atom into an organic molecule and on studying their electronic properties.

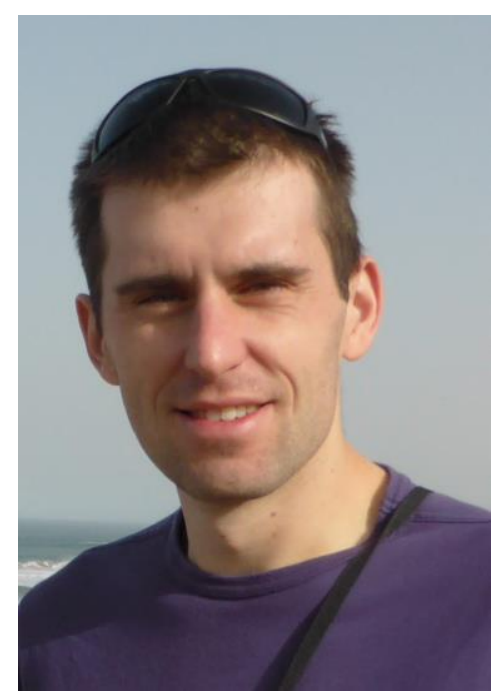

Dr Marcin Kaźmierczak is Assistant Professor at the Department of Synthesis and Structure of Organic Compounds, Faculty of Chemistry, Adam Mickiewicz University in Poznań. His doctoral thesis was carried out under the supervision of Professor Henryk Koroniak, and was defended in 2014. His research interests are focused on the chemistry of fluorinated alkyl phosphonates, as well as the application of NMR spectroscopy to determine the structures of organic compounds.

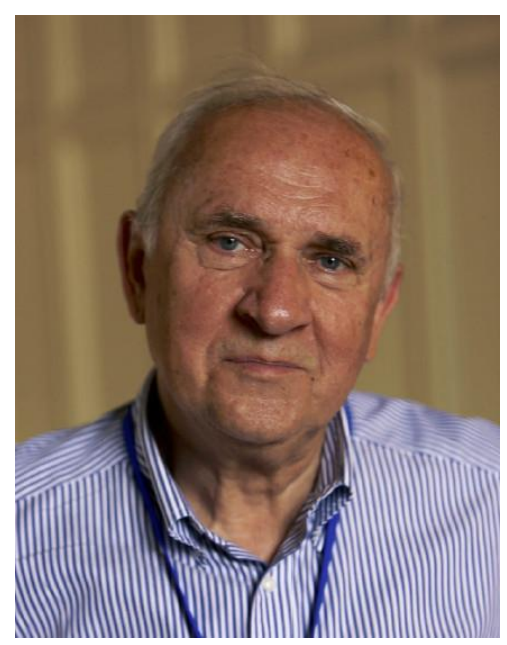

Henryk Koroniak is a Professor at Adam Mickiewicz University, Poznań, Poland. He is a Head of Department of Synthesis and Structure of Organic Compounds. His research activity includes: synthesis and structural studies of fluorine containing organic molecules, biologically active fluorochemicals, molecular modelling, and mostly fluorine influence on reactivity and structure of organic compounds. He serves presently as a Dean of Faculty of Chemistry, Adam Mickiewicz University, He was also involved is several activities related to his academic 
career such as Member of Polish State Committee for Scientific Research; Member of Editorial Board of Journal of Fluorine Chemistry; Editor of "On the borderline between chemistry and biology" (39 volumes up to 2019), Member of Council of The Foundation for Polish Science (FNP), Member of Fluorine Division, American Chemical Society.

This paper is an open access article distributed under the terms of the Creative Commons Attribution (CC BY) license (http://creativecommons.org/licenses/by/4.0/) 